\title{
Bioleaching of Indonesian Galena Concentrate With an Iron- and Sulfur-Oxidizing Mixotrophic Bacterium at Room Temperature
}

\author{
Siti Khodijah Chaerun ${ }^{1,2 *}$, Edina Amadea Putri ${ }^{1}$ and Mohammad Zaki Mubarok ${ }^{1}$ \\ ${ }^{1}$ Department of Metallurgical Engineering, Faculty of Mining and Petroleum Engineering, Institut Teknologi Bandung, \\ Bandung, Indonesia, ${ }^{2}$ Geomicrobiology-Biomining and Biocorrosion Laboratory, Microbial Culture Collection Laboratory, \\ Biosciences and Biotechnology Research Center (BBRC), Institut Teknologi Bandung, Bandung, Indonesia
}

OPEN ACCESS

Edited by:

Jinlan Xia,

Central South University, China

Reviewed by:

Zhen Yu,

Guangdong Institute

of Eco-Environmental Science and Technology, China

Eldon R. Rene,

IHE Delft Institute for Water

Education, Netherlands

*Correspondence:

Siti Khodijah Chaerun

skchaerun@gmail.com;

skchaerun@metallurgy.itb.ac.id

Specialty section:

This article was submitted to

Microbiological Chemistry

and Geomicrobiology,

a section of the journa

Frontiers in Microbiology

Received: 30 April 2020 Accepted: 10 September 2020

Published: 08 October 2020

Citation:

Chaerun SK, Putri EA and Mubarok MZ (2020) Bioleaching of Indonesian Galena Concentrate With an Iron- and Sulfur-Oxidizing Mixotrophic Bacterium at Room

Temperature.

Front. Microbiol. 11:557548. doi: 10.3389/fmicb.2020.557548
Biohydrometallurgy is believed to be a promising future study field for the recovery of lead $(\mathrm{Pb})$ from ores/concentrates since the pyrometallurgical/hydrometallurgical processes have been largely applied to recover $\mathrm{Pb}$ to date, which operates at high temperature and generates volatile $\mathrm{Pb}$ matters that are hazardous and carcinogenic to human health. Hence, the main purpose of this study was to investigate the biohydrometallurgical extraction of $\mathrm{Pb}$ from the Indonesian galena concentrate through bioleaching using an iron- and sulfur-oxidizing mixotrophic bacterium (identified as Citrobacter sp.). The bioleaching experiments were conducted in shake flasks containing the modified LB broth medium supplemented with galena concentrate with a particle size of $d_{80}=75 \mu \mathrm{m}$ at room temperature. Both semi-direct and direct bioleaching methods were employed in this study. The bacterium was able to extract lead $(\mathrm{Pb})$ from galena concentrate with high selectivity to $\mathrm{Cu}$ and $\mathrm{Zn}(0.99$ and 0.86, respectively). The highest extraction level of $90 \mathrm{~g}$ lead dissolved/ $\mathrm{kg}$ galena concentrate was achieved using direct bioleaching method at bioleaching conditions of $2 \% \mathrm{~W} / \mathrm{V}$ pulp density, $5 \mathrm{~g} / \mathrm{L} \mathrm{FeCl}_{3}, 50 \mathrm{~g} / \mathrm{L} \mathrm{NaCl}, 20 \mathrm{~g} / \mathrm{L}$ molasses and a rotation speed of $180 \mathrm{rpm}$ at room temperature $\left(25^{\circ} \mathrm{C}\right)$. The addition of $\mathrm{FeCl}_{3}, \mathrm{NaCl}$, and molasses increased the lead leaching efficiencies, which were also evidenced by the FTIR, XRD, and SEMEDS analyses. From industrial and commercial standpoints, the selective bioleaching represented in this study may be beneficial to the development of lead leaching from sulfide minerals, since insoluble anglesite $\left(\mathrm{PbSO}_{4}\right)$ precipitates are formed during ferric sulfate oxidation, thus making the recovery of lead through bioleaching unpractical.

Keywords: semi-direct bioleaching, direct bioleaching, galena, lead $(\mathrm{Pb})$, an iron- and sulfur-oxidizing mixotrophic bacterium

\section{INTRODUCTION}

Recently, the extraction of lead $(\mathrm{Pb})$ from sulfide ores relies on pyrometallurgical smelting processes and combined pyro/hydrometallurgical methods that are the high energy consumption and cause severe environmental pollution problems due to the emission of both $\mathrm{SO}_{2}$ and volatile lead matters. Hydrometallurgical routes of leaching lead 
concentrates have been developed progressively by testing a number of solvents to overcome such problems (Greet and Smart, 2002; Aydoğan et al., 2007; Long et al., 2009; Wu et al., 2014). However, the chemical solvents used are reported to have a very low solubility of lead, a high corrosiveness, and very high toxicity, and a significantly high temperature (65$85^{\circ} \mathrm{C}$ ) is required to achieve a high lead recovery as listed in Table 1 (Warren et al., 1987; Pashkov et al., 2002; Aydoğan et al., 2007; Qin et al., 2009; Zárate-Gutiérrez et al., 2010, 2015; Baba and Adekola, 2013; Wu et al., 2014; Anugrah et al., 2017; Allen and Igboayaka, 2019).

Therefore, bioleaching of lead concentrates as a biohydrometallurgical method has emerged as a possible solution for overcoming the aforementioned problems since the bioleaching is a low-cost, environmentally friendly method. Of the bacterial genera and species, Acidithiobacillus ferrooxidans and Acidithiobacillus thiooxidans (chemolithotrophs) have been employed frequently for bioleaching sulfide ores (Garcia Jr. et al., 1995; Da Silva et al., 2003; Da Silva, 2004). However, the bioleaching of galena ( $\mathrm{PbS}$ ) has been poorly studied, since the complete oxidation of galena leads to insoluble anglesite $\left(\mathrm{PbSO}_{4}\right)$ that thus precludes the recovery of lead from bioleaching and ferric sulfate leaching through conventional solvent extraction/electrowinning routes (Da Silva et al., 2003; Da Silva, 2004). Moreover, several studies demonstrated that the elevated lead bioleaching/leaching efficiencies were achieved

TABLE 1 | Previous studies on leaching lead $(\mathrm{Pb})$ from pure galena, galena concentrates, and high-grade $\mathrm{Pb}-\mathrm{Zn}$ bearing ores.

\begin{tabular}{|c|c|c|c|c|c|}
\hline Ore/mineral & $\begin{array}{l}\text { Leaching } \\
\text { agent/lixiviant }\end{array}$ & Pulp density & Leaching efficiency & $\begin{array}{l}\text { Leaching time, Temp, } \\
\text { pH }\end{array}$ & Authors \\
\hline $\begin{array}{l}\text { Galena concentrate: } \\
\text { PbS }\end{array}$ & $\begin{array}{l}0.2 \mathrm{M} \mathrm{FeCl}_{3} \\
2 \mathrm{M} \mathrm{NaCl} \\
0.1 \mathrm{M} \mathrm{HCl}\end{array}$ & $1 \%$ w/v pulp density & $\sim 100 \% \mathrm{~Pb}$ & $14 \min \left(52^{\circ} \mathrm{C}, \mathrm{pH} 2\right)$ & Warren et al., 1987 \\
\hline $\begin{array}{l}\text { Galena concentrate: } \\
\mathrm{Pb}(59.2 \text { wt. \%) } \\
\mathrm{Zn}(2.6 \text { wt. \%) }\end{array}$ & $\begin{array}{l}1 \mathrm{M} \mathrm{HNO}_{3} \\
0.01 \mathrm{M} \mathrm{Fe}\left(\mathrm{NO}_{3}\right)_{3}\end{array}$ & $5 \%$ w/v pulp density & $90 \% \mathrm{~Pb}$ & $60 \min \left(50^{\circ} \mathrm{C}\right)$ & Pashkov et al., 2002 \\
\hline $\begin{array}{l}\text { Galena concentrate: } \\
\mathrm{Pb}(79.0 \text { wt. \%) } \\
\mathrm{Zn}(1.90 \text { wt. \%) } \\
\mathrm{Cu}(0.50 \% \text { wt. } \%)\end{array}$ & $\begin{array}{l}3 \mathrm{M} \mathrm{CH}_{3} \mathrm{COOH} \\
0.5 \mathrm{M} \mathrm{H}_{2} \mathrm{O}_{2}\end{array}$ & $2 \%$ w/v pulp density & $\sim 95 \% \mathrm{~Pb}$ & $90 \min \left(50^{\circ} \mathrm{C}, \mathrm{pH} 5.1\right)$ & Aydoğan et al., 2007 \\
\hline $\begin{array}{l}\text { Galena concentrate: } \\
\text { PbS (77.24 wt. \%) } \\
\text { ZnS (0.65 wt. \%) }\end{array}$ & $\begin{array}{l}75 \mathrm{~g} / \mathrm{L} \mathrm{FeCl}_{3} \cdot 6 \mathrm{H}_{2} \mathrm{O} \\
\mathrm{NaCl} 250 \mathrm{~g} / \mathrm{L} \\
0.1 \mathrm{M} \mathrm{HCl}\end{array}$ & $\mathrm{N} / \mathrm{A}$ & $\begin{array}{l}97.39 \% \mathrm{PbS} \text { converted } \\
\text { to } \mathrm{PbCl}_{2}\end{array}$ & $40 \min \left(90^{\circ} \mathrm{C}, \mathrm{pH} 2\right)$ & Qin et al., 2009 \\
\hline 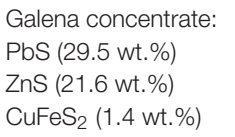 & $0.65 \mathrm{M} \mathrm{HNO}_{3}$ & $10 \%$ w/v pulp density & $\begin{array}{l}80 \% \mathrm{~Pb} \\
100 \% \mathrm{Ag}\end{array}$ & $\begin{array}{l}90 \min \left(130^{\circ} \mathrm{C}, \mathrm{pH}\right. \\
0.69)\end{array}$ & $\begin{array}{l}\text { Zárate-Gutiérrez et al., } \\
2010\end{array}$ \\
\hline $\begin{array}{l}\text { Galena ore: } \\
\text { Pb (58.66 wt. \%) } \\
\text { Zn (0.16 wt. \%) }\end{array}$ & $\begin{array}{l}1 \mathrm{M} \text { tributylphosphate } \\
\text { in } 100 \% \mathrm{MIBK}\end{array}$ & $2 \%$ w/v pulp density & $92.1 \% \mathrm{~Pb}$ & $30 \min \left(25^{\circ} \mathrm{C}, \mathrm{pH} 5\right)$ & $\begin{array}{l}\text { Baba and Adekola, } \\
2013\end{array}$ \\
\hline $\begin{array}{l}\text { Galena concentrate: } \\
\mathrm{Pb}(54.27 \text { wt. \%) } \\
\mathrm{Zn}(15.29 \text { wt. \%) }\end{array}$ & $\begin{array}{l}\text { Acidic ferric } \\
\text { methanesulfonate } \\
\text { solution }\end{array}$ & $0.4 \%$ w/v pulp density & $\sim 100 \% \mathrm{~Pb}$ & $\begin{array}{l}10 \min \left(65-85^{\circ} \mathrm{C}\right. \\
\mathrm{pH}<3)\end{array}$ & Wu et al., 2014 \\
\hline $\begin{array}{l}\text { Galena concentrate: } \\
\text { PbS (24.9 wt. \%) } \\
\text { ZnS (21.6 wt. \%) } \\
\text { CuFeS }_{2}(1.4 \text { wt. \%) }\end{array}$ & $\begin{array}{l}1 \mathrm{M} \mathrm{Na}_{3} \mathrm{Cit} \\
0.04 \mathrm{M} \mathrm{H}_{2} \mathrm{O}_{2}\end{array}$ & $10 \%$ w/v pulp density & $100 \% \mathrm{~Pb}$ & $120 \min \left(25^{\circ} \mathrm{C}, \mathrm{pH} 7\right)$ & $\begin{array}{l}\text { Zárate-Gutiérrez et al., } \\
2015\end{array}$ \\
\hline $\begin{array}{l}\text { Galena concentrate: } \\
\mathrm{Pb}(66.6 \text { wt. \%) } \\
\mathrm{Zn}(7.38 \text { wt. \%) }\end{array}$ & $\begin{array}{l}\text { 3.44 } \mathrm{M} \mathrm{H}_{2} \mathrm{SiF} \\
9.80 \mathrm{M} \mathrm{H}_{2} \mathrm{O}_{2}\end{array}$ & $12 \%$ w/v pulp density & $99.26 \% \mathrm{~Pb}$ & $135 \min \left(97^{\circ} \mathrm{C}\right)$ & Anugrah et al., 2017 \\
\hline $\begin{array}{l}\text { High-grade Pb ore: } \\
\mathrm{Pb}(31.75 \text { wt.\%) } \\
\text { Zn (0.93 wt.\%) } \\
\mathrm{Cu}(0.53 \text { wt.\%) }\end{array}$ & $2.15 \mathrm{M} \mathrm{HNO}_{3}$ & $20 \%$ w/v pulp density & $\sim 33 \% \mathrm{~Pb}$ & $150 \min \left(70^{\circ} \mathrm{C}\right)$ & $\begin{array}{l}\text { Allen and Igboayaka, } \\
2019\end{array}$ \\
\hline
\end{tabular}


in the presence of $\mathrm{NaCl}$ (Warren et al., 1987; Liao and Deng, 2004; Ye et al., 2017), $\mathrm{FeCl}_{3}$ (Dutrizac, 1986; Kim et al., 1986; Warren et al., 1987; Dutrizac and Chen, 1990; Long et al., 2009), and ferric $\left(\mathrm{Fe}^{3+}\right)$ ions (Pashkov et al., 2002). Hence, the present study investigated the use of a local mixotrophic bacterium (identified as Citrobacter sp.) capable of oxidizing iron and sulfur as well as producing biosurfactants, including EPS (extracellular polymeric substances) in extracting lead from galena concentrate

TABLE 2 | Previous studies and the current study on bioleaching lead (Pb) from pure galena, galena concentrates, and high-grade Pb- $\mathrm{Zn}$ bearing ores.

\begin{tabular}{|c|c|c|c|c|c|}
\hline Ore/mineral & $\begin{array}{l}\text { Medium and pulp } \\
\text { density }\end{array}$ & Microbes employed & $\begin{array}{l}\text { Bioleaching } \\
\text { efficiency }\end{array}$ & $\begin{array}{l}\text { Bioleaching time, } \\
\text { Temp, pH }\end{array}$ & Authors \\
\hline Pure galena (PbS) & $\begin{array}{l}\text { Mineral salts solution } \\
\text { containing } 0.4 \mathrm{~g} / \mathrm{L} \text { each } \\
\left(\mathrm{NH}_{4}\right)_{2} \mathrm{SO}_{4} \text {, } \\
\mathrm{MgSO}_{4} .7 \mathrm{H}_{2} \mathrm{O} \text {, and } \\
\mathrm{K}_{2} \mathrm{HPO}_{4} \\
(2.5-5 \% \mathrm{w} / \mathrm{v} \text { pulp } \\
\text { density) }\end{array}$ & $\begin{array}{l}\text { Acidithiobacillus } \\
\text { thiooxidans or } \\
\text { Acidithiobacillus } \\
\text { ferrooxidans }\end{array}$ & $1.1-5$ mg/L Pb & 29 days $\left(24^{\circ} \mathrm{C}, \mathrm{pH} 2\right)$ & Garcia Jr. et al., 1995 \\
\hline $\begin{array}{l}\text { Pure galena }(\mathrm{PbS}) \text { : } \\
85.6 \text { wt. \% Pb }\end{array}$ & $\begin{array}{l}\text { MS medium containing } \\
3 \mathrm{~g} / \mathrm{L}\left(\mathrm{NH}_{4}\right)_{2} \mathrm{SO}_{4} \\
0.5 \mathrm{~g} / \mathrm{L} \mathrm{KH}_{2} \mathrm{PO}_{4} \\
0.5 \mathrm{~g} / \mathrm{L} \mathrm{MgSO}_{4} \\
(2 \% \mathrm{w} / \mathrm{v} \text { pulp density) }\end{array}$ & At. ferrooxidans & $\sim 90 \% \mathrm{~Pb}$ & 4 days $\left(30^{\circ} \mathrm{C}, \mathrm{pH} 2.8\right)$ & Bang et al., 1995 \\
\hline $\begin{array}{l}\text { A natural galena: } \\
\text { PbS (60.9 wt.\% Pb) } \\
\text { ZnS (15.2 wt. \% Zn) }\end{array}$ & $\begin{array}{l}\text { Modified Kelly } \\
\text { Medium = MKM } \\
\text { containing } 0.4 \mathrm{~g} / \mathrm{L} \\
\left(\mathrm{NH}_{4}\right)_{2} \mathrm{SO}_{4}, 0.4 \mathrm{~g} / \mathrm{L} \\
\mathrm{MgSO}_{4} .7 \mathrm{H}_{2} \mathrm{O}, 0.04 \mathrm{~g} / \mathrm{L} \\
\text { potassium } \\
\text { orthophosphate } \\
\text { (10\% w/v pulp density) }\end{array}$ & $\begin{array}{l}\text { A mixed culture of } \\
\text { At. thiooxidans, } \\
\text { At.ferrooxidans, } \\
\text { Leptospirillum } \\
\text { ferrooxidans }\end{array}$ & $\begin{array}{l}34 \% \mathrm{~Pb} \\
1 \% \mathrm{Zn}\end{array}$ & 6 days $\left(35^{\circ} \mathrm{C}, \mathrm{pH} 2\right)$ & Da Silva et al., 2003 \\
\hline $\begin{array}{l}\text { A natural galena: } \\
\text { PbS (60.9 wt.\% Pb) } \\
\text { ZnS (15.2 wt. \% Zn) }\end{array}$ & $\begin{array}{l}\text { Modified Kelly } \\
\text { Medium = MKM } \\
\text { (10\% w/v pulp density) }\end{array}$ & $\begin{array}{l}\text { A mixed culture of } A t \text {. } \\
\text { thiooxidans, } A t \text {. } \\
\text { ferrooxidans, } L \text {. } \\
\text { ferrooxidans }\end{array}$ & $34 \% \mathrm{~Pb}$ & 6 days $\left(35^{\circ} \mathrm{C}, \mathrm{pH} 2\right)$ & Da Silva, 2004 \\
\hline $\begin{array}{l}\text { Galena concentrate: } \\
\text { PbS ( } 80 \%) \\
\text { ZnS ( 5\%) }\end{array}$ & $\begin{array}{l}2 \mathrm{~K} \text { medium } \\
\text { (5\% w/v pulp density) }\end{array}$ & At. ferrooxidans & $\begin{array}{l}\text { 43\% Pb (9.8 mg/L Pb) } \\
99 \% \text { Zn (196 mg/L Zn) }\end{array}$ & 16 days $\left(25^{\circ} \mathrm{C}, \mathrm{pH} 2\right)$ & Pacholewska, 2004 \\
\hline $\begin{array}{l}\text { Galena: } \\
\text { Pb (79.5 wt.\%) } \\
\text { Zn (1.92 wt.\%) } \\
\text { Cu (0.17 wt.\%) }\end{array}$ & $\begin{array}{l}\text { 9K medium } \\
\text { (3.8\% w/v pulp density) }\end{array}$ & At. ferrooxidans & $\begin{array}{l}0.01098 \mathrm{~mol} / \mathrm{L} \\
(=2.27 \mathrm{~g} / \mathrm{L}) \mathrm{Pb} \\
\mathrm{Zn}(\mathrm{N} / \mathrm{A})\end{array}$ & 6 days $\left(30^{\circ} \mathrm{C}, \mathrm{pH} 2\right)$ & Jiang et al., 2008 \\
\hline $\begin{array}{l}\text { Galena ore: } \\
\text { PbS (58.7\%) } \\
\text { ZnS }(0.16 \%)\end{array}$ & $\begin{array}{l}\text { Agarose-simulated } 9 \mathrm{~K} \\
\text { medium } \\
\text { (10\% w/v pulp density) }\end{array}$ & $\begin{array}{l}\text { A mixed culture of } \\
\text { acidophilic bacteria } \\
\text { predominantly } A t \text {. } \\
\text { ferrooxidans }\end{array}$ & $\begin{array}{l}89 \% \mathrm{~Pb} \\
92 \% \mathrm{Zn}\end{array}$ & 5 days $\left(35^{\circ} \mathrm{C}, \mathrm{pH} 2\right)$ & Baba et al., 2011 \\
\hline $\begin{array}{l}\text { Galena concentrate: } \\
\text { PbS (90\%) } \\
\text { ZnS }(7.5 \%) \\
\text { CuFeS2 }(0.7 \%)\end{array}$ & $\begin{array}{l}\text { T\&K medium } \\
\text { (10\% w/v pulp density) }\end{array}$ & $\begin{array}{l}\text { A mixed culture of } A t \text {. } \\
\text { ferrooxidans and } A t \text {. } \\
\text { thiooxidans }\end{array}$ & $\begin{array}{l}57 \% \mathrm{~Pb} \\
\mathrm{Zn}(\mathrm{N} / \mathrm{A})\end{array}$ & 30 days $\left(30^{\circ} \mathrm{C}, \mathrm{pH} 1.8\right)$ & Mejía et al., 2012 \\
\hline $\begin{array}{l}\text { High-grade } \mathrm{Zn-Pb} \\
\text { bearing ore: } \\
\mathrm{PbS}(12.4 \%) \\
\mathrm{ZnS}(40.71 \%)\end{array}$ & $\begin{array}{l}\text { 9K medium } \\
\text { (5\% w/v pulp density) }\end{array}$ & $\begin{array}{l}\text { A mixed culture of iron- } \\
\text { and sulfur-oxidizing } \\
\text { moderately } \\
\text { thermophilic acidophilic } \\
\text { chemolithotrophic } \\
\text { bacteria }\end{array}$ & $\begin{array}{l}0.027 \% \mathrm{~Pb} \\
98.5 \% \mathrm{Zn}\end{array}$ & 25 days $\left(45^{\circ} \mathrm{C}, \mathrm{pH} 1\right)$ & Ghassa et al., 2014 \\
\hline 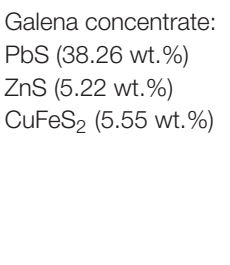 & $\begin{array}{l}\text { LB medium } \\
\text { supplemented with } \\
5 \mathrm{~g} / \mathrm{L} \mathrm{FeCl} 3,50 \mathrm{~g} / \mathrm{L} \\
\mathrm{NaCl}, 20 \mathrm{~g} / \mathrm{L} \text { molasses } \\
\text { (2-5\% w/v pulp density) }\end{array}$ & $\begin{array}{l}\text { An iron- and } \\
\text { sulfur-oxidizing } \\
\text { mixotrophic bacterium } \\
\text { (Citrobacter sp.) }\end{array}$ & $\begin{array}{l}90 \mathrm{~g} \mathrm{~Pb} / \mathrm{kg} \text { concentrate } \\
(=1.8 \mathrm{~g} / \mathrm{L} \mathrm{Pb}) \\
2.3 \mathrm{~g} \mathrm{Zn} / \mathrm{kg} \\
\text { concentrate } \\
(=46 \mathrm{mg} / \mathrm{L}) \\
1.9 \mathrm{~g} \mathrm{Cu} / \mathrm{kg} \\
\text { concentrate } \\
\text { (=39 } \mathrm{mg} / \mathrm{L} \mathrm{Cu})\end{array}$ & $\begin{array}{l}7 \text { days }\left(25^{\circ} \mathrm{C}, \mathrm{pH}\right. \\
3-4.7)\end{array}$ & Current study \\
\hline
\end{tabular}


to enhance lead recovery. Compared to previous studies on galena $(\mathrm{PbS})$ bioleaching and high-grade $\mathrm{Pb}$ ores bioleaching summarized in Table 2 (Bang et al., 1995; Garcia Jr. et al., 1995; Da Silva et al., 2003; Da Silva, 2004; Pacholewska, 2004; Jiang et al., 2008; Baba et al., 2011; Mejía et al., 2012; Ghassa et al., 2014), the present study is different from previous studies and more beneficial from metallurgical standpoints as follows: (1) the bacterium Citrobacter sp. employed in this study belongs to mixotrophic group capable of utilizing both organic and inorganic compounds for energy and carbon sources, thus making much easier for industrial applications since bacterial carbon sources can be derived from any organic wastes abundant in Indonesia and many other tropical countries; (2) the lead bioleaching in this study only employs a pure bacterial culture (herein Citrobacter sp.) that is able to oxidize both iron and sulfur as well as proliferate at high $\mathrm{NaCl}$ concentration and highly resistant to toxic metals, while previous studies mostly utilize a mixed culture of chemolithoautotrophs dominated by Acidithiobacillus ferrooxidans, Acidithiobacillus thiooxidans and Leptospirillum ferrooxidans that are very sensitive to organic compounds; (3) The lead bioleaching in this study takes place at room temperature $\left(25^{\circ} \mathrm{C}\right)$ and the $\mathrm{pH}$ range of 3.5-4.6 that are more advantageous to energy-saving lead leaching process and the reduced usage of expensive anti-corrosive materials; (4) Medium used in this study contains $\mathrm{NaCl}$, which elevates lead bioleaching efficiencies where $\mathrm{NaCl}$ can be replaced with seawater that is commonly used in many metallurgy and mining industries, thus providing a cost-effective lead leaching technology; (5) By using this local mixotrophic bacterium Citrobacter sp., the lead bioleaching from the galena concentrate is selective to $\mathrm{Cu}$ and $\mathrm{Zn}$, thereby providing a selective lead leaching process that is profitable for subsequent $\mathrm{Cu}$ and $\mathrm{Zn}$ leaching processes since $\mathrm{Pb}(\mathrm{PbS})$ in association with $\mathrm{CuFeS}_{2}$ and $\mathrm{ZnS}$ always makes passivation layers that hinder $\mathrm{Cu}$ and Zn dissolution; (6) The bacterium Citrobacter sp. also produces biosurfactants (including EPS) that are useful for maintaining $\mathrm{Fe}^{3+}$ solubilization at $\mathrm{pH}>4.0$.

Therefore, the specific aims of the current study were: (1) to investigate biohydrometallurgical leaching process of Indonesian galena concentrates (the main composition of $\mathrm{PbS}, \mathrm{CuFeS}_{2}$, and $\mathrm{ZnS}$ ) by the local mixotrophic bacterium Citrobacter sp. at room temperature $\left(25^{\circ} \mathrm{C}\right)$ by employing two different bioleaching methods (i.e., semi-direct and direct bioleaching) and utilizing the $\mathrm{LB}$ medium supplemented with $\mathrm{FeCl}_{3}, \mathrm{NaCl}$ and molasses to minimize the formation of $\mathrm{PbSO}_{4}$ precipitates, which had the low solubility of lead within a sulfate system, (2) to evaluate the effect of different molasses concentrations on lead bioleaching efficiency since the bacterium Citrobacter sp. produced high amounts of biosurfactants by consuming organic carbon (herein molasses), and (3) to assess the effect of different $\mathrm{NaCl}$ and $\mathrm{FeCl}_{3}$ concentrations on lead bioleaching efficiency since the presence of $\mathrm{NaCl}$ and $\mathrm{FeCl}_{3}$ enhanced lead recovery. The findings of this study may provide further insights into the bioleaching of galena that is rarely studied due to insoluble anglesite formation and the toxicity of high lead content in galena to microbes. For our knowledge, this is the first report on the selective bioleaching of lead sulfide ores (herein galena concentrate) from Indonesia that is always associated with sphalerite and chalcopyrite using the local mixotrophic bacterium Citrobacter sp. in molassessupplemented medium containing high $\mathrm{NaCl}$ concentration, which thus has potential industrial application since most of the metallurgy and mining industries use seawater in their mineral processing operations.

\section{MATERIALS AND METHODS}

\section{Bacterium and Growth Medium}

A local mixotrophic bacterium used in this study was isolated from an Indonesian mine site (designated SKC2), which has the ability to oxidize iron and sulfur and produce extracellular polymeric substances (EPS) (Mubarok et al., 2017). Based on the 16S rRNA sequencing analysis, this bacterium was identified as Citrobacter sp. ( $98.45 \%$ similarity). The LB broth medium (10 g/L tryptone, $5 \mathrm{~g} / \mathrm{L}$ yeast extract, $10 \mathrm{~g} / \mathrm{L} \mathrm{NaCl}$ ) was used for both semi-direct and direct bioleaching experiments since the preliminary experiments in screening the appropriate medium for lead bioleaching with this bacterium showed the higher lead extraction than the modified Fe-broth medium $[0.5 \mathrm{~g} / \mathrm{L}$ $\mathrm{MgSO}_{4} .7 \mathrm{H}_{2} \mathrm{O}, 3 \mathrm{~g} / \mathrm{L}\left(\mathrm{NH}_{4}\right)_{2} \mathrm{SO}_{4}, 0.5 \mathrm{~g} / \mathrm{L} \mathrm{K}_{2} \mathrm{HPO}_{4}, 0.1 \mathrm{~g} / \mathrm{L} \mathrm{KCl}$, $0.5 \mathrm{~g} / \mathrm{L}$ tryptone, $5 \mathrm{~g} / \mathrm{L} \mathrm{Na}_{2} \mathrm{~S}_{2} \mathrm{O}_{3} .5 \mathrm{H}_{2} \mathrm{O}$, and $1 \mathrm{~g} / \mathrm{L} \mathrm{FeSO}_{4} .7 \mathrm{H}_{2} \mathrm{O}$ ]. In addition, molasses was obtained from a sugar company, Padalarang, West Java, Indonesia.

\section{Galena Concentrate}

The galena concentrate employed in this study was kindly provided by an Indonesian mining company in Bogor, West Java, Indonesia $\left(06^{\circ} 29^{\prime} \mathrm{S}\right.$ and $\left.106^{\circ} 33^{\prime} \mathrm{E}\right)$, with a particle size of $d_{80}=75 \mu \mathrm{m}$. ED-XRF analysis of the concentrate determined its chemical composition, as summarized in Table 3. X-ray

TABLE 3 | Elemental composition of Indonesian galena concentrate used in this study.

\begin{tabular}{lc}
\hline Element & wt. (\%) \\
\hline $\mathrm{Pb}$ & 38.26 \\
$\mathrm{Fe}$ & 8.73 \\
$\mathrm{~S}$ & 8.00 \\
$\mathrm{Cu}$ & 5.55 \\
$\mathrm{Zn}$ & 5.22 \\
$\mathrm{Si}$ & 1.04 \\
$\mathrm{Al}$ & 0.365 \\
$\mathrm{Mg}$ & 0.157 \\
$\mathrm{Mn}$ & 0.0826 \\
$\mathrm{Ca}$ & 0.0623 \\
$\mathrm{Cd}$ & 0.0540 \\
$\mathrm{~K}$ & 0.0496 \\
$\mathrm{As}$ & 0.0370 \\
$\mathrm{U}$ & 0.0208 \\
$\mathrm{Ga}$ & 0.0186 \\
$\mathrm{Se}$ & 0.0132 \\
$\mathrm{P}$ & 0.0116 \\
$\mathrm{Ti}$ & 0.0056
\end{tabular}



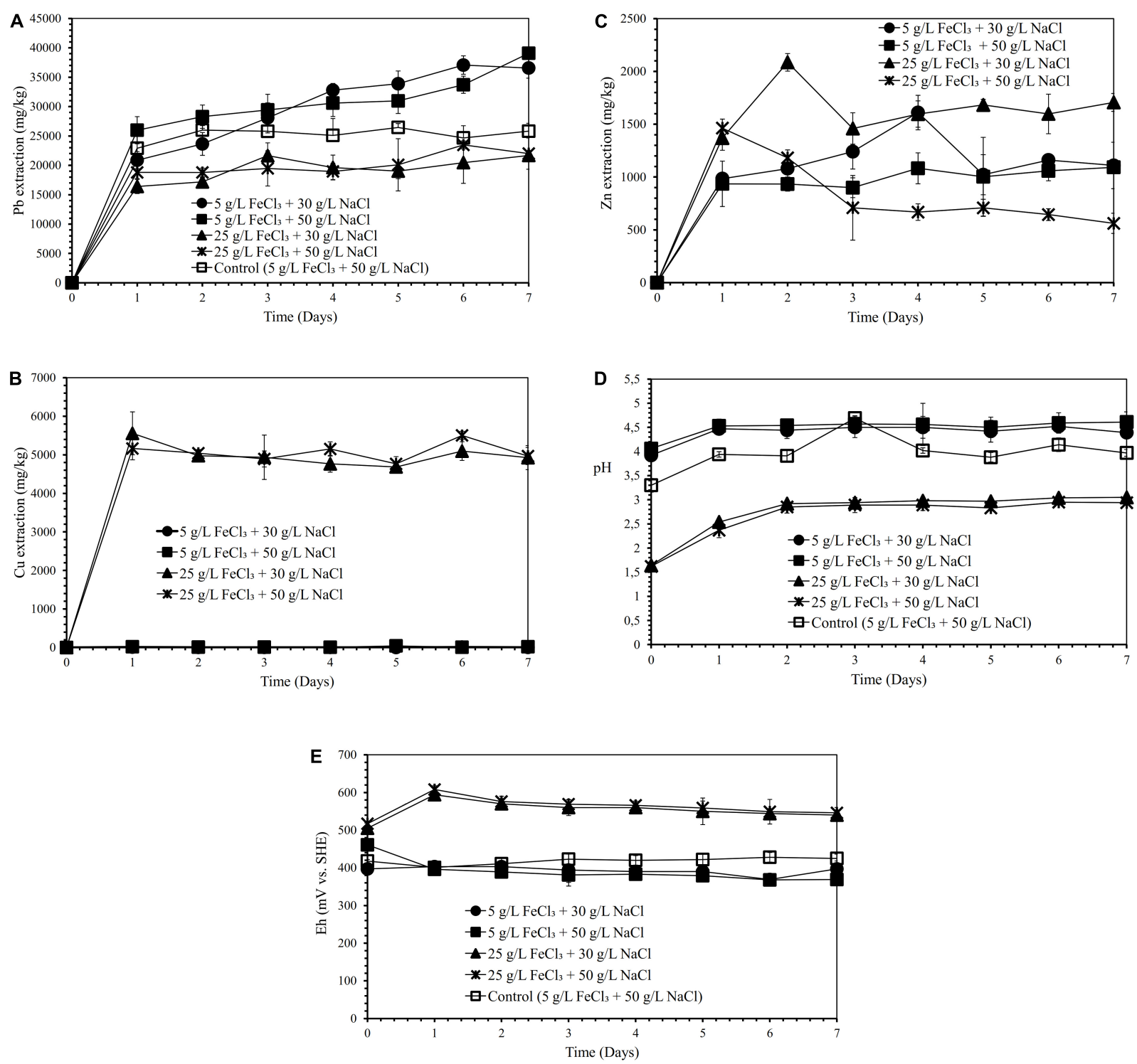

FIGURE 1 | Lead (Pb) extraction (mg Pb dissolved/kg galena concentrate) (A), Copper (Cu) extraction (mg Cu dissolved/kg galena concentrate) (B), Zinc (Zn) extraction (C) ( $\mathrm{mg}$ Zn dissolved/kg galena concentrate), pH (D) and Eh ( $\mathrm{mV}$ vs. SHE) (E) of the galena concentrate semi-direct bioleaching suspension by an ironand sulfur-oxidizing mixotrophic bacterium (Citrobacter sp.) at various concentrations of $\mathrm{FeCl}_{3}(5$ and $25 \mathrm{~g} / \mathrm{L}$ ) and $\mathrm{NaCl}(30$ and $50 \mathrm{~g} / \mathrm{L})$ at bioleaching parameters of $15 \% \mathrm{v} / \mathrm{v}$ bacterial inoculum, $5 \% \mathrm{~W} / \mathrm{v}$ pulp density, $10 \mathrm{~g} / \mathrm{L}$ molasses, a rotation speed of $180 \mathrm{rpm}$ over a 7 -day period of the experiment in comparison with those of the abiotic control semi-direct leaching (without bacteria) at $5 \mathrm{~g} / \mathrm{L} \mathrm{FeCl}_{3}$ and $50 \mathrm{~g} / \mathrm{L} \mathrm{NaCl}$.

powder diffractometry (XRD) analysis showed its mineralogical composition in which galena was predominant in the concentrate sample with a low amount of other minerals such as chalcopyrite and sphalerite (data not shown).

\section{Experimental Procedure}

Two leaching experiments were performed in this study: (1) semi-direct bioleaching experiments, and (2) direct bioleaching experiments. Bioleaching experiments were conducted in duplicate in sterile $300 \mathrm{ml}$ Erlenmeyer flasks containing $150 \mathrm{ml}$ of bacterial growth medium (LB medium) under aerobic conditions. The growth medium was then supplemented with various concentrations of $\mathrm{FeCl}_{3}(5,15$, and $25 \mathrm{~g} / \mathrm{L} \mathrm{FeCl}$ ), $\mathrm{NaCl}(30$ and $50 \mathrm{~g} / \mathrm{L} \mathrm{NaCl})$ and molasses $(10,20$, and $30 \mathrm{~g} / \mathrm{L}$ molasses) at various pulp densities ( 2 and $5 \% \mathrm{w} / \mathrm{v}$ ) of the galena concentrate, and the $\mathrm{pH}$ was adjusted to 4.0 with $\mathrm{HCl}$. Molasses was supplemented to enable the bacterium Citrobacter sp. to generate large amounts of biosurfactants (including EPS), thus being capable of preventing ferric $\left(\mathrm{Fe}^{3+}\right)$ ions and $\mathrm{PbSO}_{4}$ precipitation. Bacterial inoculum $(15 \% v / v)$ was subsequently introduced into bioleaching suspension, and the cultures were then incubated for 7 days at room temperature $\left(25^{\circ} \mathrm{C}\right)$ with shaking at $180 \mathrm{rpm}$. Periodically, the $\mathrm{pH}$ of the suspension was measured using a $\mathrm{pH}$ meter (Lutron PE-03), while the 
redox potential (Eh) of the suspension was measured using an ORP electrode with $\mathrm{Ag} / \mathrm{AgCl}$ reference (Lutron ORP-14). The solution $(5 \mathrm{ml})$ was removed daily for measuring dissolved metal concentration by using atomic absorption spectrophotometer (AAS; Shimadzu AA-6300, Japan). The percentage of metal extraction $(\mathrm{Pb}, \mathrm{Cu}$, and $\mathrm{Zn})$ and selectivity for lead leaching by iron- and sulfur-oxidizing mixotrophic bacterium to $\mathrm{Cu}\left(\mathrm{S}_{\mathrm{Cu}}\right)$ and to $\mathrm{Zn}\left(\mathrm{S}_{\mathrm{Zn}}\right)$ were calculated using the equations as described in our earlier work (Chaerun et al., 2017). After 7 days of bioleaching, separate sets of samples (i.e., the galena concentrate residues resulting from the experiments which led to the highest lead extraction for both semi-direct and direct bioleaching experiments) were made up and prepared for analysis by X-ray powder diffraction analysis (XRD; Rigaku Smartlab), Fourier transform infrared (FTIR Prestige 21, Shimadzu, Japan) and scanning electron microscopy equipped with energy dispersive spectroscopy (SEM-EDS; JEOL JSM-J6510 A). Samples were washed three times with deionized water before being observed by FTIR and XRD, while XRD measurement was carried out using $\mathrm{Cu}-\mathrm{K} \alpha$ radiation, generated at $40 \mathrm{kV}$ and $30 \mathrm{~mA}$, using the $2 \theta / \theta$ method at a scan speed of $2 \% / \mathrm{min}$. For SEM-EDS observation, samples were fixed with $2.5 \% \mathrm{v} / \mathrm{v}$ glutaraldehyde in $5 \mathrm{mM}$ phosphate buffer at $\mathrm{pH} 7.0$ for $24 \mathrm{~h}$ at $4^{\circ} \mathrm{C}$, washed twice with $5 \mathrm{mM}$ phosphate buffer, dehydrated in a graded series of acetone $(25,50,75$, and $100 \%)$ for $15 \mathrm{~min}, 15 \mathrm{~min}, 15 \mathrm{~min}$, and $24 \mathrm{~h}$, respectively.

For semi-direct bioleaching experiments, the galena concentrate was introduced into the culture medium after 3 days of incubation. For direct bioleaching experiments, the concentrate was introduced into the medium at the onset of the experiments. In comparison, the abiotic control leaching experiments were also conducted to ensure the bacterial participation in lead bioleaching processes, which were identical to those for semi-direct and direct bioleaching experiments, except that the bacterium was not added. The data are presented as the averages obtained from the duplicate experiments, and error bars represent standard deviation. Also, biosurfactant production by the mixotrophic bacterium during its bacterial growth for $48 \mathrm{~h}$ was assayed by measuring the emulsifying activity index (EI, \%) following the work of Berg et al. (1990) with modification (Chaerun et al., 2018). This assay was conducted to confirm the role of the generated biosurfactants (including EPS as high-molecular-weight biosurfactants) in promoting lead bioleaching efficiencies. Briefly, the sample (2 $\mathrm{mL}$ ) of the bacterial culture broth was mixed with $5 \mathrm{~mL}$ of TM buffer, which contained $20 \mathrm{mmol}$ Tris- $\mathrm{HCl}$ buffer $(\mathrm{pH}$ 7.0) and $10 \mathrm{mmol} \mathrm{MgSO}_{4} .7 \mathrm{H}_{2} \mathrm{O}$ per liter of deionized water, followed by addition of $1 \mathrm{~mL}$ coconut oil. After the mixture was vortexed for $3 \mathrm{~min}$ and incubated at room temperature for $1 \mathrm{~min}$, the first turbidity (A1) of the aqueous phase was measured at $600 \mathrm{~nm}$. Subsequently, after the mixture was incubated at room temperature for $60-90 \mathrm{~min}$, the second turbidity (A2) of the aqueous phase was measured. Emulsifying activity index (EI, \%) was then expressed in Eq. (1).

$$
E I=\left(1-\frac{O D_{600} \text { of } \mathrm{A} 2}{O D_{600} \text { of } \mathrm{A} 1}\right) \times 100
$$

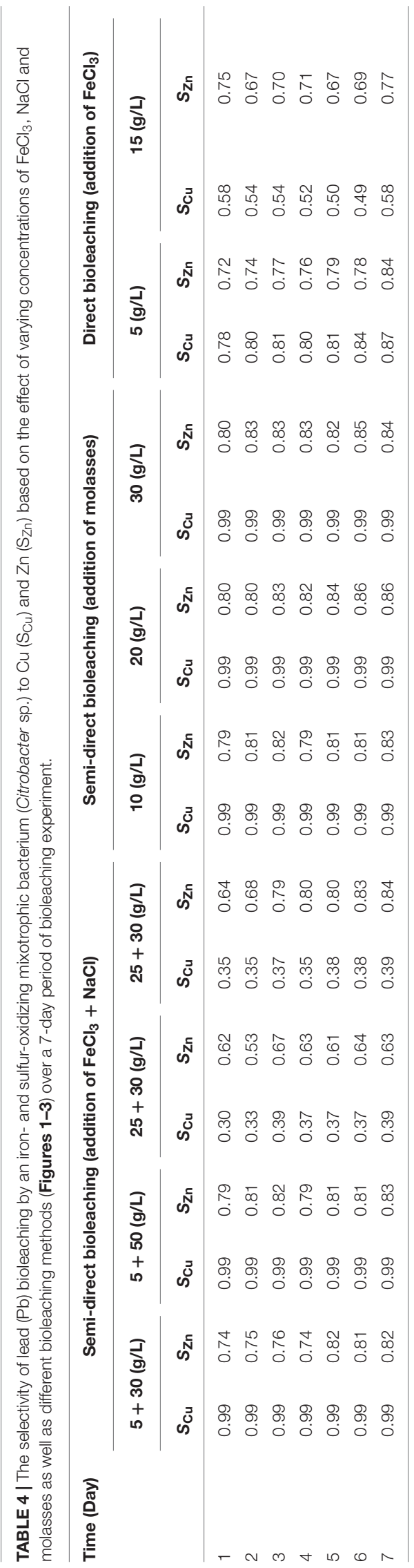

Frontiers in Microbiology | www.frontiersin.org 

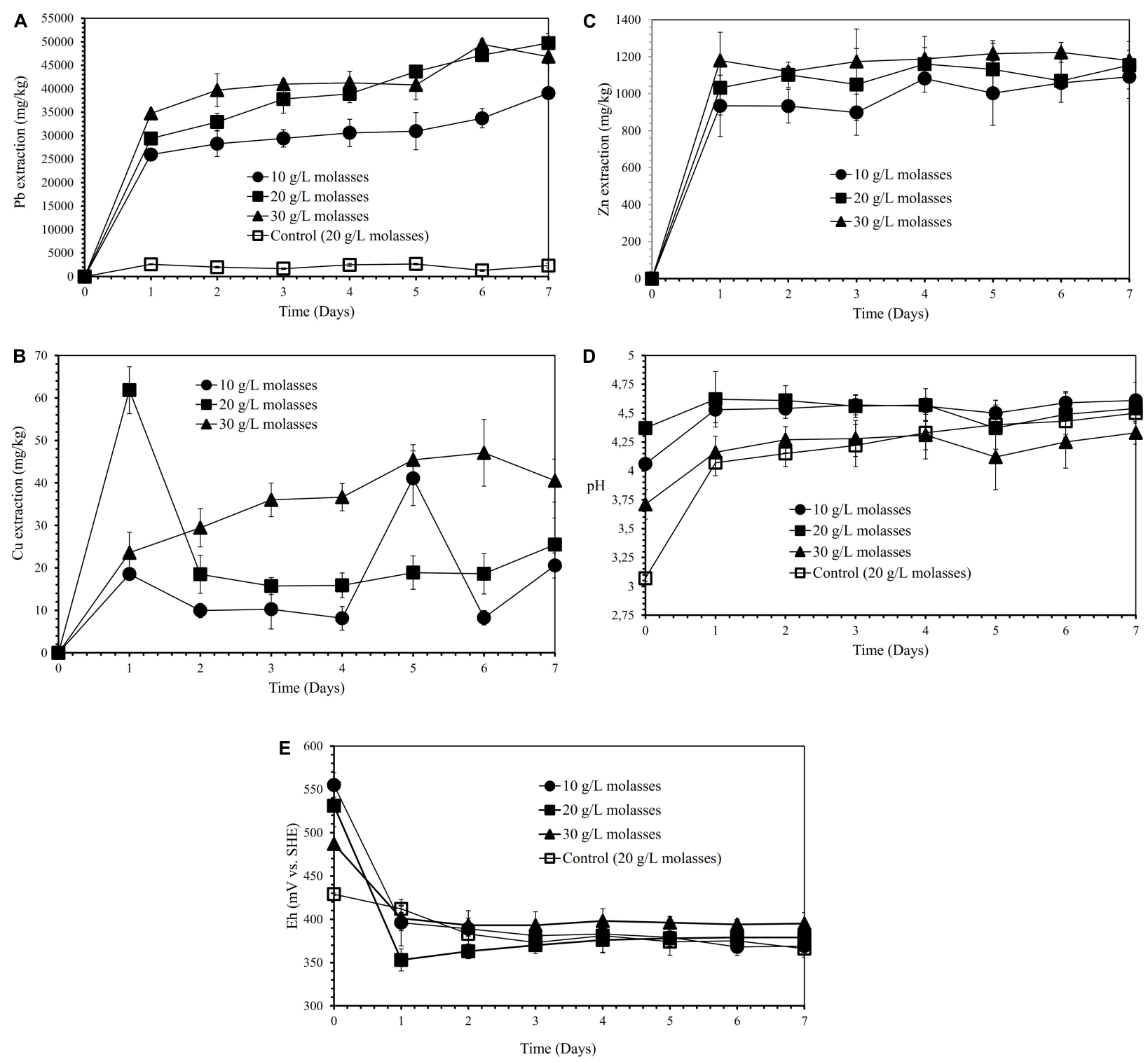

FIGURE 2 | Lead (Pb) extraction (mg Pb dissolved/kg galena concentrate) (A), Copper (Cu) extraction (mg Cu dissolved/kg galena concentrate) (B), Zinc (Zn) extraction (C) ( $\mathrm{mg}$ Zn dissolved/kg galena concentrate), $\mathrm{pH}$ (D) and Eh ( $\mathrm{mV}$ vs. SHE) (E) of the galena concentrate semi-direct bioleaching suspension by an ironand sulfur-oxidizing mixotrophic bacterium (Citrobacter sp.) at various molasses concentrations (10, 20, and $30 \mathrm{~g} / \mathrm{L}$ ) at bioleaching parameters of $15 \% \mathrm{~V} / \mathrm{V}$ bacterial inoculum, $5 \% \mathrm{w} / \mathrm{v}$ pulp density, $5 \mathrm{~g} / \mathrm{L} \mathrm{FeCl}_{3}, 50 \mathrm{~g} / \mathrm{L} \mathrm{NaCl}$, a rotation speed of $180 \mathrm{rpm}$ over a 7 -day period of the experiment in comparison with those of the abiotic control semi-direct leaching (without bacteria) at $20 \mathrm{~g} / \mathrm{L}$ molasses.

\section{RESULTS AND DISCUSSION}

\section{Semi-Direct Bioleaching}

Semi-direct bioleaching experiments were conducted by adding various concentrations of $\mathrm{FeCl}_{3}(5$ and $25 \mathrm{~g} / \mathrm{L}), \mathrm{NaCl}(30$ and $50 \mathrm{~g} / \mathrm{L})$ and molasses $(10,20$, and $30 \mathrm{~g} / \mathrm{L})$ at $5 \%$ $w / v$ pulp density to evaluate their effects on lead recovery. Figures 1A-C demonstrate the effect of various concentrations of $\mathrm{FeCl}_{3}(5$ and $25 \mathrm{~g} / \mathrm{L})$ and $\mathrm{NaCl}(30$ and $50 \mathrm{~g} / \mathrm{L})$ on lead, copper and zinc extraction (mg metals of $\mathrm{Pb}$, $\mathrm{Cu}, \mathrm{Zn}$ dissolved per $\mathrm{kg}$ concentrate; $\mathrm{mg} / \mathrm{kg}$ ) by iron- and sulfur-oxidizing mixotrophic bacterium (Citrobacter sp.) in the semi-direct bioleaching of the galena concentrate over a 7 day period of the experiment at bioleaching parameters of $15 \%$ $v / v$ bacterial inoculum, $5 \% \mathrm{w} / v$ pulp density, and $10 \mathrm{~g} / \mathrm{L}$ molasses. Lead bioleaching efficiencies from the concentrate increased rapidly during the first 1 day and subsequently increased slightly for the remaining bioleaching time, which achieved the extraction levels of $37-39 \mathrm{~g} / \mathrm{kg}$ (for the addition of $5 \mathrm{~g} / \mathrm{L} \mathrm{FeCl} 3$ with $30 \mathrm{~g} / \mathrm{L}$ or $50 \mathrm{~g} / \mathrm{L} \mathrm{NaCl}$ ) and $22 \mathrm{~g} / \mathrm{kg}$ (for the addition of $25 \mathrm{~g} / \mathrm{L} \mathrm{FeCl}_{3}$ with $30 \mathrm{~g} / \mathrm{L}$ or $50 \mathrm{~g} / \mathrm{L} \mathrm{NaCl}$ ) (Figure 1A). These increments were concomitant with an increase in copper and 

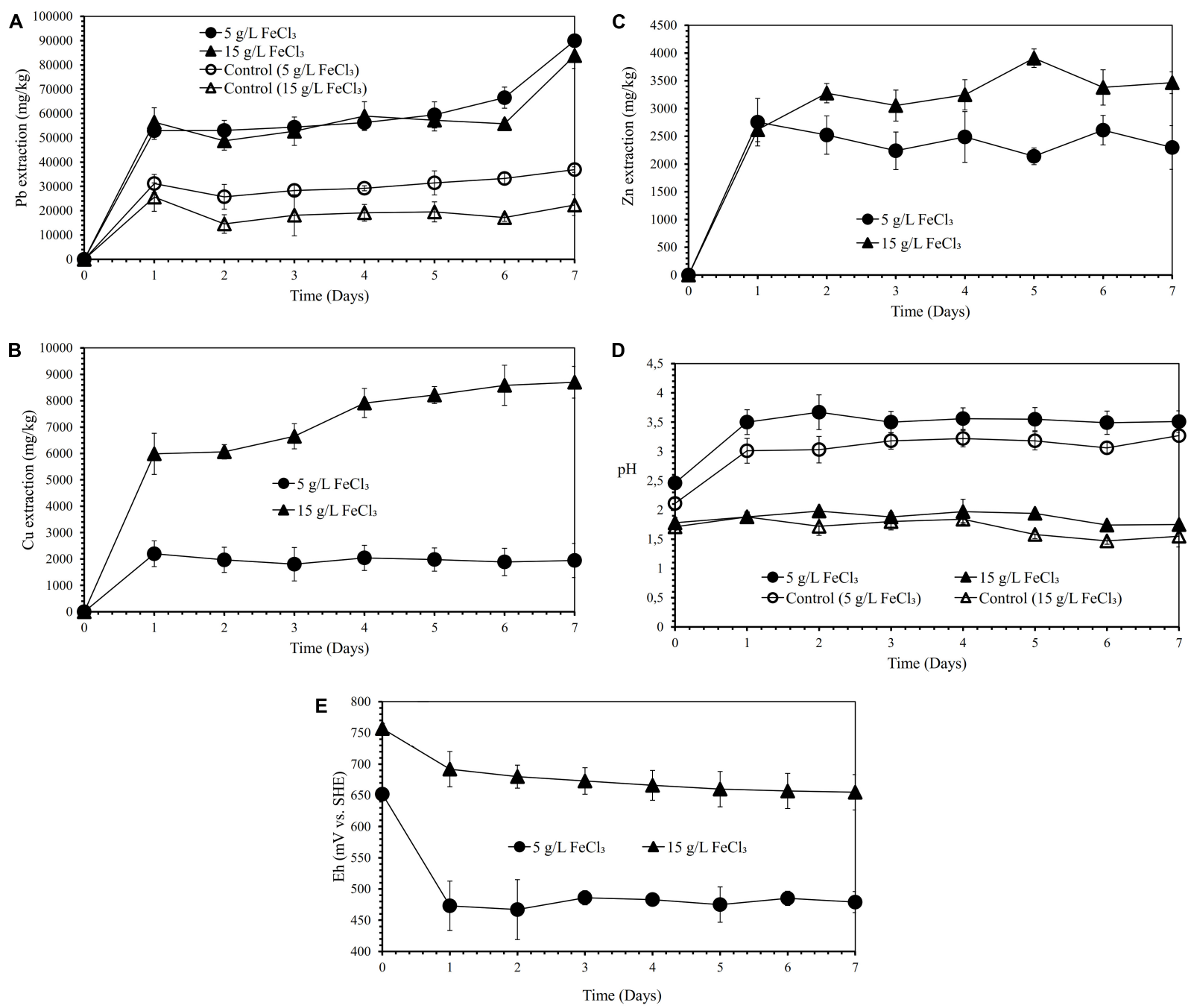

FIGURE 3 | Lead ( $\mathrm{Pb}$ ) extraction (mg Pb dissolved/kg galena concentrate) (A), Copper (Cu) extraction (mg Cu dissolved/kg galena concentrate) (B), Zinc (Zn) extraction (C) ( $\mathrm{mg}$ Zn dissolved/kg galena concentrate), pH (D) and Eh ( $\mathrm{mV}$ vs. SHE) (E) of the galena concentrate direct bioleaching suspension by an iron- and sulfur-oxidizing mixotrophic bacterium (Citrobacter sp.) and the abiotic control direct leaching (without bacteria) at various FeCl 3 concentrations (5 and $15 \mathrm{~g} / \mathrm{L}$ ) at bioleaching parameters of $15 \% \mathrm{v} / \mathrm{v}$ bacterial inoculum, $2 \% \mathrm{~W} / \mathrm{v}$ pulp density, $20 \mathrm{~g} / \mathrm{L}$ molasses, $50 \mathrm{~g} / \mathrm{L} \mathrm{NaCl}$, a rotation speed of $180 \mathrm{rpm}$ over a 7 -day period of the experiment.

zinc bioleaching efficiencies (Figures 1B,C), except for copper dissolution with the addition of $5 \mathrm{~g} / \mathrm{L} \mathrm{FeCl}_{3}$ with $30 \mathrm{~g} / \mathrm{L}$ or $50 \mathrm{~g} / \mathrm{L}$ $\mathrm{NaCl}$ which was negligible (Figure 1B). Zinc dissolution was quite low compared to lead and copper extraction, thus being considered to be selective bioleaching to zinc. No difference was observed for lead extraction from the galena concentrate at any $\mathrm{NaCl}$ concentration $(30 \mathrm{~g} / \mathrm{L}$ or $50 \mathrm{~g} / \mathrm{L} \mathrm{NaCl}$ ), and its extraction was apparently governed by the presence of $\mathrm{FeCl}_{3}$, of which $5 \mathrm{~g} / \mathrm{L}$ was the best concentration (Figure 1A). The presence of $\mathrm{FeCl}_{3}$ also affected the initial $\mathrm{pH}$ of the suspension, where the higher $\mathrm{FeCl}_{3}$ concentration introduced into the solution yielded the more acidic suspension (Figure 1D). This lower $\mathrm{pH}$ was a result of the hydrolysis of $\mathrm{FeCl}_{3}$, generating $\mathrm{HCl}$, which therefore lowered the suspension $\mathrm{pH}$. Moreover, the $\mathrm{pH}$ of the suspensions tended to increase over time as a result of sulfide mineral oxidation that consumed proton $\left(\mathrm{H}^{+}\right)$, whereas the suspension Eh values containing the higher $\mathrm{FeCl}_{3}$ concentration $(25 \mathrm{~g} / \mathrm{L})$ were observed to be higher than those containing the lower $\mathrm{FeCl}_{3}$ concentration $(5 \mathrm{~g} / \mathrm{L})$ due to the oxidizing capacity of $\mathrm{FeCl}_{3}$, which had a more oxidizing agent of $\mathrm{Fe}^{3+}$ (Figure 1E). Since the semi-direct bioleaching at $5 \mathrm{~g} / \mathrm{L} \mathrm{FeCl}_{3}$ and $50 \mathrm{~g} / \mathrm{L} \mathrm{NaCl}$ was highly selective to $\mathrm{Cu}\left(S_{\mathrm{Cu}}=0.99\right)$ and was relatively selective to $\mathrm{Zn}\left(S_{\mathrm{Zn}}=0.83\right)$ (Figures $\mathbf{1 B}, \mathbf{C}$ and Table 4$)$, hereafter the concentration was used for further bioleaching experiments to enhance the extraction of $\mathrm{Pb}$ as well as to prevent the formation of $\mathrm{PbSO}_{4}$ precipitates as well as ferric $\left(\mathrm{Fe}^{3+}\right)$ ion precipitation by adding organic compounds (herein molasses).

Figures 2A-C show the effects of various molasses concentrations $(10,20$, and $30 \mathrm{~g} / \mathrm{L})$ on lead, copper, and zinc extraction ( $\mathrm{mg}$ metals of $\mathrm{Pb}, \mathrm{Cu}, \mathrm{Zn}$ dissolved per $\mathrm{kg}$ 


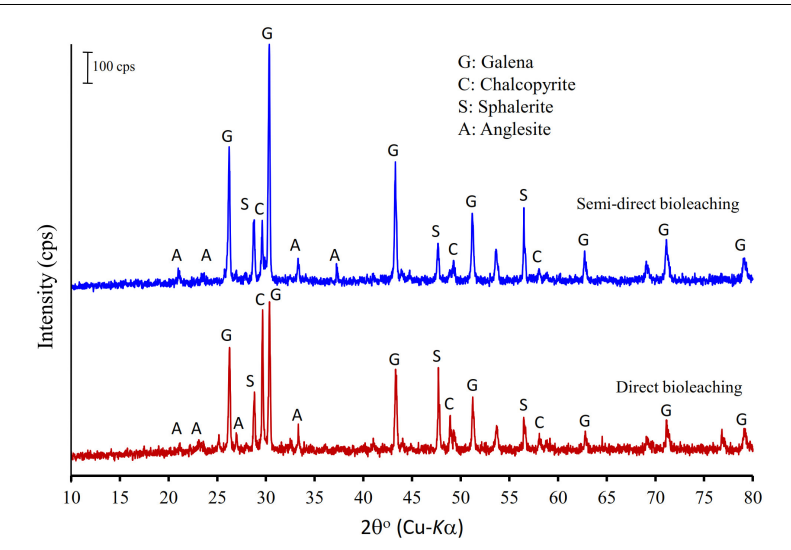

FIGURE 4 | X-ray powder diffraction patterns of the galena concentrate residues in semi-direct bioleaching at bioleaching parameters of $5 \% \mathrm{~W} / \mathrm{v}$ pulp density, $5 \mathrm{~g} / \mathrm{L} \mathrm{FeCl}_{3}, 50 \mathrm{~g} / \mathrm{L} \mathrm{NaCl}, 20 \mathrm{~g} / \mathrm{L}$ molasses and in the direct bioleaching at bioleaching parameters of $2 \% \mathrm{w} / \mathrm{v}$ pulp density, $5 \mathrm{~g} / \mathrm{L} \mathrm{FeCl}_{3}$, $50 \mathrm{~g} / \mathrm{L} \mathrm{NaCl}, 20 \mathrm{~g} / \mathrm{L}$ molasses by iron- and sulfur-oxidizing mixotrophic bacterium (Citrobacter sp.) after 7 days of the bioleaching experiment.

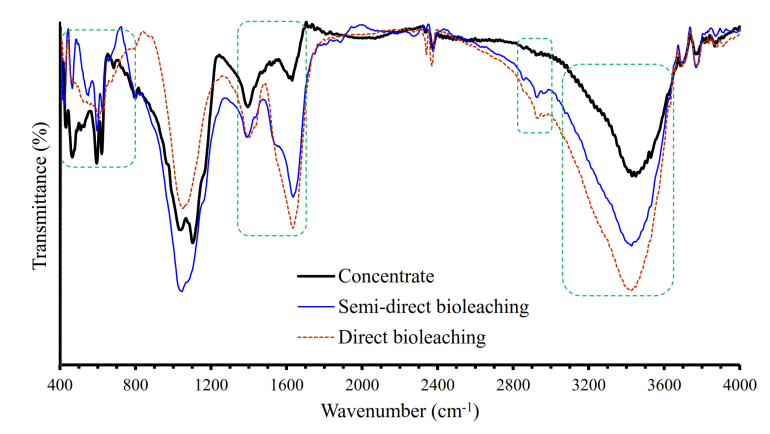

FIGURE 5 | Fourier transform infrared (FTIR) spectra of the galena concentrate residues in semi-direct bioleaching at bioleaching parameters of $5 \% \mathrm{w} / \mathrm{v}$ pulp density, $5 \mathrm{~g} / \mathrm{L} \mathrm{FeCl}_{3}, 50 \mathrm{~g} / \mathrm{L} \mathrm{NaCl}, 20 \mathrm{~g} / \mathrm{L}$ molasses and in the direct bioleaching at bioleaching parameters of $2 \% \mathrm{~W} / \mathrm{V}$ pulp density, $5 \mathrm{~g} / \mathrm{L}$ $\mathrm{FeCl}_{3}, 50 \mathrm{~g} / \mathrm{L} \mathrm{NaCl}, 20 \mathrm{~g} / \mathrm{L}$ molasses by iron- and sulfur-oxidizing mixotrophic bacterium (Citrobacter sp.) after 7 days of the bioleaching experiment.

concentrate; $\mathrm{mg} / \mathrm{kg}$ ) by iron- and sulfur-oxidizing mixotrophic bacterium (Citrobacter sp.) in semi-direct bioleaching of the galena concentrate over 7 days of the experiment at bioleaching parameters of $15 \% \mathrm{v} / \mathrm{v}$ bacterial inoculum, $5 \% \mathrm{w} / \mathrm{v}$ pulp density, $5 \mathrm{~g} / \mathrm{L} \mathrm{FeCl}{ }_{3}$ and $50 \mathrm{~g} / \mathrm{L} \mathrm{NaCl}$. Lead extraction $(39 \sim 50 \mathrm{~g} / \mathrm{kg})$ from the concentrate was observed for three different molasses concentrations tested, and molasses concentration of 20 and $30 \mathrm{~g} / \mathrm{L}$ appeared to bring about higher lead extraction than that of $10 \mathrm{~g} / \mathrm{L}$. The lead bioleaching efficiencies from the concentrate increased rapidly during the first 1 day and subsequently increased slightly for another 6 days (Figure 2A). It appeared that the addition of molasses created selective bioleaching, the high selectivity for copper, and the relatively high selectivity for zinc (Figures 2B,C and Table 4). During the bioleaching experiments, the suspension $\mathrm{pH}$ tended to increase, while the Eh otherwise decreased (Figures 2D,E). Since $20 \mathrm{~g} / \mathrm{L}$ molasses was the best concentration for lead extraction with the high selectivity of lead bioleaching to $\mathrm{Cu}\left(S_{\mathrm{Cu}}=0.99\right)$ and $\mathrm{Zn}\left(S_{\mathrm{Zn}}=0.86\right)$, hereafter, the concentration was used in the subsequent experiments (direct bioleaching experiments).

\section{Direct Bioleaching}

Figures $3 \mathrm{~A}-\mathrm{C}$ show the effects of various $\mathrm{FeCl}_{3}$ concentrations (5 and $15 \mathrm{~g} / \mathrm{L}$ ) on lead, copper, and zinc extraction (mg metals of $\mathrm{Pb}, \mathrm{Cu}, \mathrm{Zn}$ dissolved/kg galena concentrate) by ironand sulfur-oxidizing mixotrophic bacterium (Citrobacter sp.) in the direct bioleaching of the galena concentrate over a 7 day period of the experiment at bioleaching parameters of $15 \%$ $v / v$ bacterial inoculum, $2 \% \mathrm{w} / v$ pulp density, $20 \mathrm{~g} / \mathrm{L}$ molasses, and $50 \mathrm{~g} / \mathrm{L} \mathrm{NaCl}$. Through the direct bioleaching method, a higher level of $\mathrm{Pb}$ extraction $(84 \sim 90 \mathrm{~g} / \mathrm{kg})$ than semi-direct bioleaching was observed for two $\mathrm{FeCl}_{3}$ concentrations (5 and $15 \mathrm{~g} / \mathrm{L}$ ) examined (Figure 3A). However, no significant difference was observed for lead extraction in both $\mathrm{FeCl}_{3}$ concentrations. Again, the lead bioleaching efficiencies from galena concentrate increased rapidly during the first 1 day, subsequently remained relatively constant for another 5 days, and slightly increased up to $7 \mathrm{~d}$ of bioleaching period. These increases occurred simultaneously with an increase in copper and zinc extraction (Figures 3B,C) with the exception of copper dissolution at $5 \mathrm{~g} / \mathrm{L} \mathrm{FeCl}_{3}$, which was quite low (Figure 3B). It was suggested from the results of this study that the direct bioleaching of galena concentrate at $5 \mathrm{~g} / \mathrm{L} \mathrm{FeCl}_{3}$ led to the high selectivity of lead bioleaching to copper $\left(S_{\mathrm{Cu}}=\sim 0.9\right)$ and was relatively selective to zinc $\left(S_{\mathrm{Zn}}=0.84\right)$ (Figures 3B,C and Table 4). Again, the initial $\mathrm{pH}$ of the suspensions containing the higher $\mathrm{FeCl}_{3}$ concentration resulted in more acidic suspension, and the $\mathrm{pH}$ values of the bacterial suspensions tended to elevate due to sulfide oxidation (Figure 3D). In contrast, the suspension Eh values tended to decline over time (Figure 3E). From the results of the lead extraction (Figures 1A, 2A, 3A), the lead extraction levels in control leaching were lower than those achieved in the bioleaching, indicating that the bacteria greatly participated in the lead bioleaching.

\section{Characterization of Galena Concentrate Residues After Bioleaching}

Figure 4 shows the XRD patterns of the galena concentrate and its residues in semi-direct bioleaching and direct bioleaching after 7 days of the bioleaching experiments. Both bioleaching techniques led to the formation of anglesite, thus hindering the enhancement of $\mathrm{Pb}$ extraction from the concentrate (Figures 2A, 3A). In addition, galena remained as a predominant mineral in leach residues in association with a small amount of chalcopyrite and sphalerite. From the XRD spectra, changes in mineralogical structure due to bioleaching were not discernible; hence FTIR analysis was performed to investigate chemical bondings in galena concentrate before and after bioleaching (Figure 5). The FTIR spectrum of starting galena concentrate contains bands at $400-800 \mathrm{~cm}^{-1}$ (inorganic components such as minerals and clays), $621 \mathrm{~cm}^{-1}$ (C-S stretching), 1,000$1,230 \mathrm{~cm}^{-1}$ (Si-O stretching), $\sim 1,081 \mathrm{~cm}^{-1}$ (C-O stretching vibrations of C-O-C groups, e.g., cellulose), $\sim 1,400 \mathrm{~cm}^{-1}$ 

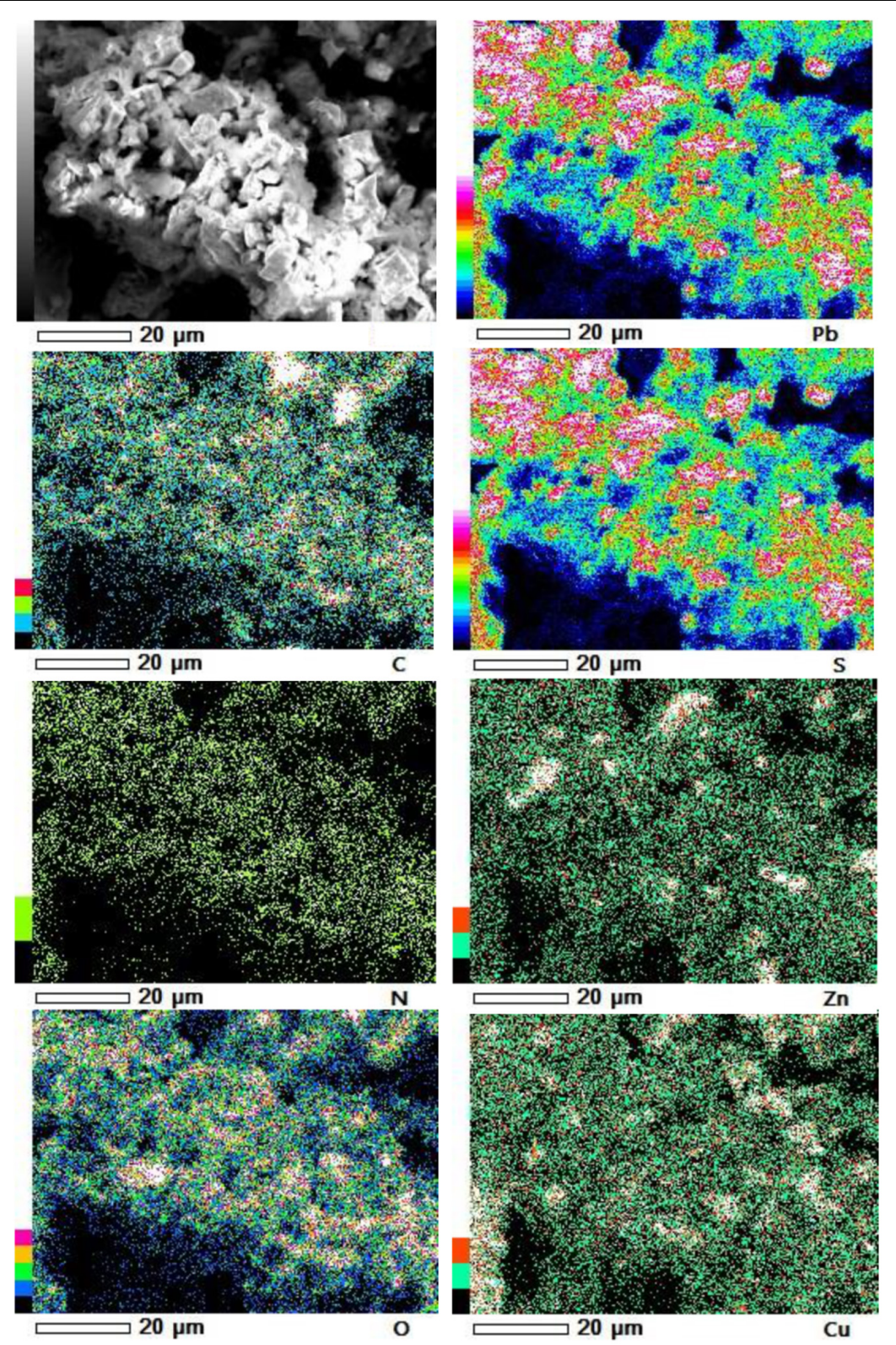

FIGURE 6 | SEM-EDS maps of elemental compositions of the galena concentrate residues in semi-direct bioleaching at bioleaching parameters of $5 \%$ $w / v$ pulp density, $5 \mathrm{~g} / \mathrm{L} \mathrm{FeCl}_{3}, 50 \mathrm{~g} / \mathrm{L} \mathrm{NaCl}, 20 \mathrm{~g} / \mathrm{L}$ molasses by iron- and sulfur-oxidizing mixotrophic bacterium (Citrobacter sp.) after 7 days of the bioleaching experiment.

(carboxylic and carbonylic groups), 1,620-1,640 $\mathrm{cm}^{-1}$ (hydrophilic $\mathrm{C}=\mathrm{O}$ groups), and $3,000-3,700 \mathrm{~cm}^{-1}(\mathrm{O}-\mathrm{H}$ stretching, $\mathrm{H}$-bonds, and $\mathrm{OH}$-groups). It exhibited that the bands at $400-800 \mathrm{~cm}^{-1}$ (inorganic components such as minerals including galena) were reduced after bioleaching (both semidirect and direct bioleaching processes) but not before the bioleaching process (as galena concentrate) (Figure 5). This reduction could be as a result of the bacterial role in bioleaching lead from galena concentrate, which was also supported by the sharp peaks of the leach residues at 1,385 and $1,535-1,660 \mathrm{~cm}^{-1}$ as an obvious indicator of the presence of bacterial cells (Chaerun et al., 2013). Moreover, the increased intensity of a broad band at 3,000-3,600 $\mathrm{cm}^{-1}$ (H-bonds and OH-groups) and two peaks at 2,860 and $2,920 \mathrm{~cm}^{-1}$ (asymmetric and symmetric $\mathrm{C}-\mathrm{H}$ stretching vibrations of $\mathrm{CH}_{3}$ and $\mathrm{CH}_{2}$ groups) were observed for the leach residues. These results indicated that the residues retained more water and hydrophobic organic matters than the concentrates, which corresponded to the presence of extracellular polymeric substances (EPS) generated by the bacteria in this study. This observation is in agreement with the result of Chaerun et al. (2013), who reported that EPS, as a hygroscopic, highly hydrated biopolymer has the ability to retain water entropically. Other works also provide additional support for our FTIR results on EPS generation, demonstrating 

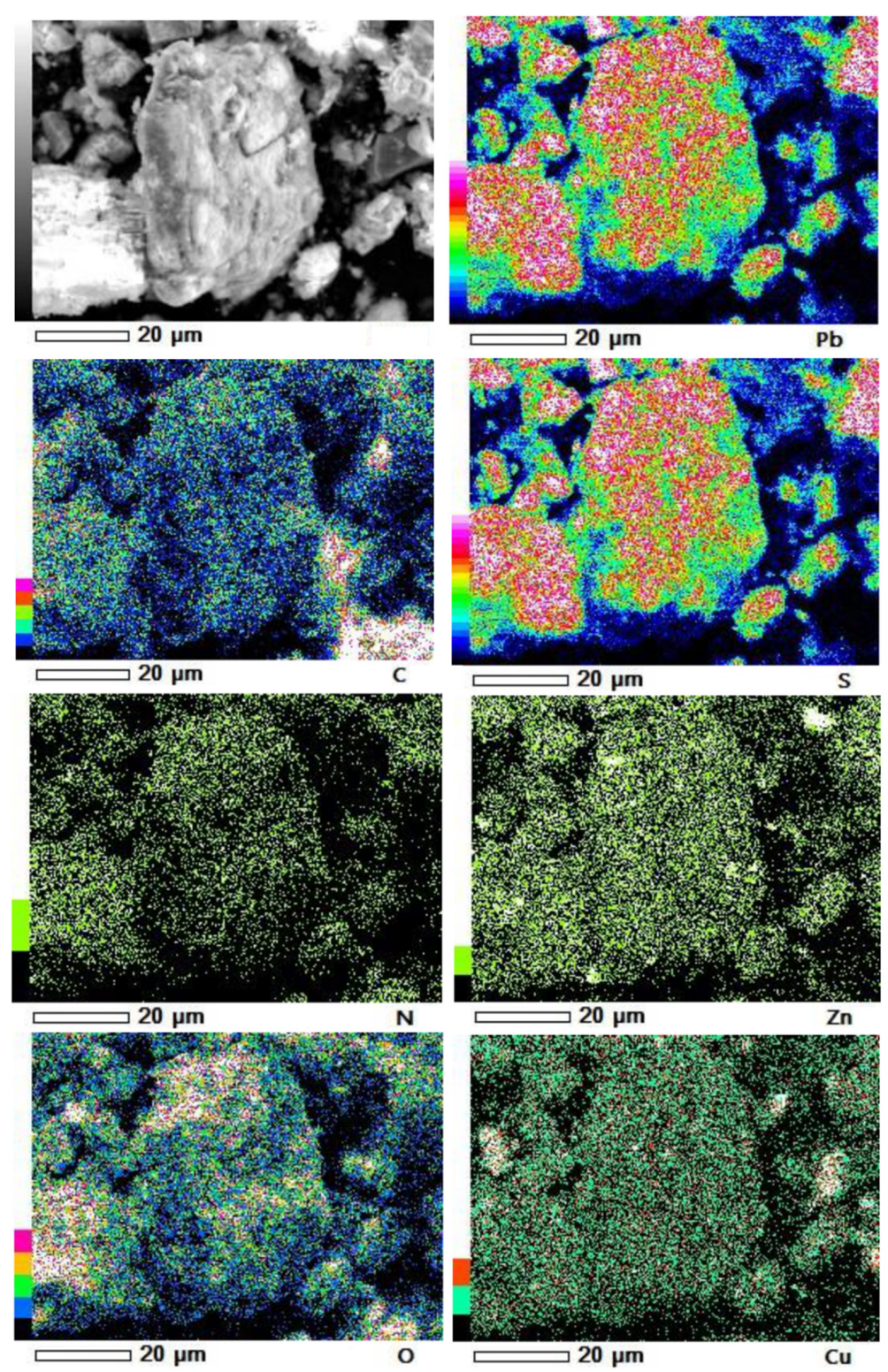

FIGURE 7 | SEM-EDS maps of elemental compositions of the galena concentrate residues in the direct bioleaching at bioleaching parameters of $2 \%$ $W / v$ pulp density, $5 \mathrm{~g} / \mathrm{L} \mathrm{FeCl}_{3}, 50 \mathrm{~g} / \mathrm{L} \mathrm{NaCl}, 20 \mathrm{~g} / \mathrm{L}$ molasses by iron- and sulfur-oxidizing mixotrophic bacterium (Citrobacter sp.) after 7 days of the bioleaching experiment.

that the EPS is cell-bound and causes the bacterial cell surface to become more hydrophobic due to the hydrophobic properties of the EPS (Govender and Gericke, 2011) that are attributed to compounds, such as polysaccharide-linked methyl and acetyl groups (Flemming and Wingender, 2010).

Furthermore, our SEM-EDS mapping observation of the galena concentrate residues (Figures 6, 7) also supports this hypothesis in that an iron- and sulfur-oxidizing mixotrophic bacterium (Citrobacter sp.) used in this study generates EPS, which thus forms the EPS-concentrate complexes and is consequently able to promote the interfacial degradation of the galena concentrate as well as the bioleaching of lead from the concentrate. This was represented by the formation of aggregates as a result of bacterial attachment to galena surfaces (due to EPS), which was also evidenced by the presence of $\mathrm{C}$ and $\mathrm{N}$ in the residues as the main component of bacterial cells and EPS content (Figures 6, 7). Small amounts of $\mathrm{Cu}$ and $\mathrm{Zn}$ revealed by SEM-EDS mapping observation in this study also confirmed the bioleaching of lead, copper, and zinc, as shown in Figures 2, 3. This result was also supported by the elemental contents of the residues (Table 5), demonstrating larger amounts of C, N, P, and smaller amounts of $\mathrm{Pb}, \mathrm{Cu}, \mathrm{Zn}$ in the residues than in the concentrate. In addition to FTIR and SEM-EDS observations, the role of EPS generated by the bacterium in elevating the lead bioleaching efficiencies rapidly during the first 1 day (Figures 1A, 2A, 3A) was also confirmed by the biosurfactant production (as represented 
TABLE 5 | Elemental concentration ( $\left.{ }^{\mathbf{a}}\right)$ of Indonesian galena concentrate after 7 days of bioleaching by an iron- and sulfur-oxidizing mixotrophic bacterium (Citrobacter sp.).

\begin{tabular}{|c|c|}
\hline Element & wt. (\%) \\
\hline $\mathrm{Pb}$ & $7.18(0.19) \sim 18.63(0.09)^{b}$ \\
\hline $\mathrm{Fe}$ & $3.15(1.28)$ \\
\hline S & $11.99(2.58)$ \\
\hline $\mathrm{Cu}$ & $1.34(0.56)$ \\
\hline $\mathrm{Zn}$ & n.d. \\
\hline $\mathrm{Si}$ & $0.03(0) \sim 0.47(0)$ \\
\hline Al & $0.28(0.005)$ \\
\hline $\mathrm{Mg}$ & $0.04(0.01)$ \\
\hline $\mathrm{Mn}$ & n.d. \\
\hline $\mathrm{Ca}$ & $0.03(0)$ \\
\hline Cd & $0.07(0)$ \\
\hline K & - \\
\hline As & $2.14(0.43)$ \\
\hline$\cup$ & n.d. \\
\hline $\mathrm{Ga}$ & n.d. \\
\hline Se & n.d. \\
\hline$P$ & $0.38(0.02)$ \\
\hline $\mathrm{Ti}$ & $0.04(0)$ \\
\hline C & $40.7(1.3)$ \\
\hline N & $6.4(0.5)$ \\
\hline $\mathrm{O}$ & $20.36(3.28)$ \\
\hline
\end{tabular}

n.d., not detected; "-", not measured; abased on quantitative ED-XRF analyses $(n=2-4) ;{ }^{b}$ standard deviation.

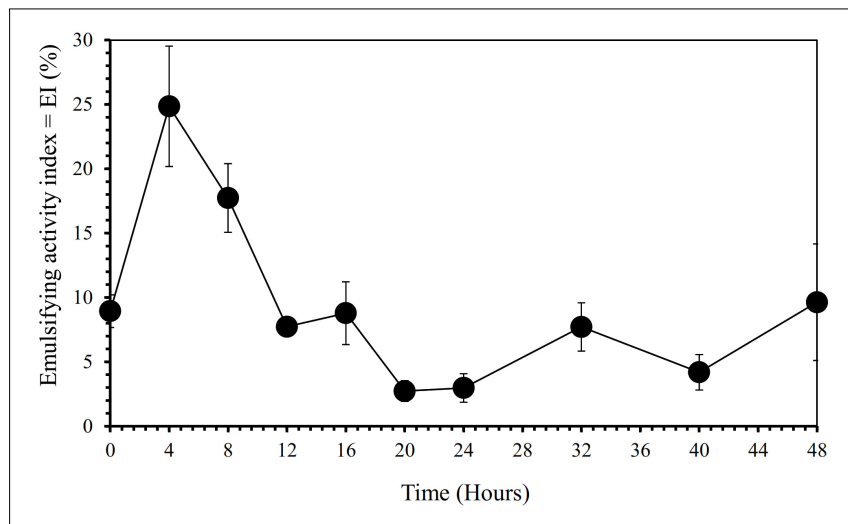

FIGURE 8 | Biosurfactant production by iron- and sulfur-oxidizing mixotrophic bacterium (Citrobacter sp.) as represented by emulsifying activity index (El in $\%)$ over $48 \mathrm{~h}$ of the bacterial growth in the modified LB medium.

by emulsifying activity index $=\mathrm{EI}$ ) of the bacterium over $48 \mathrm{~h}$ of bacterial growth in the modified LB medium, demonstrating that the highest biosurfactant production was attained at $4 \mathrm{~h}$ of bacterial growth (Figure 8).

From the results of this study, it could be seen that both semi-direct and direct bioleaching took place at the $\mathrm{pH}$ range of $1.6 \sim 4.6$ at which the bacterium Citrobacter sp. used in this study was able to proliferate, which had $\mathrm{pH}$ optima near neutrality and minimum and maximum $\mathrm{pH}$ values for growth 1.5 and 9.5, respectively. Meanwhile, both semi-direct and direct bioleaching exhibited the elevated lead extraction levels $(\sim 50$ and $\sim 90 \mathrm{~g} / \mathrm{kg}$, respectively) compared with copper $(\sim 0.03$ and $\sim 2 \mathrm{~g} / \mathrm{kg}$, respectively) and zinc ( $\sim 1$ and $\sim 2.3 \mathrm{~g} / \mathrm{kg}$, respectively) extraction levels (Figures $\mathbf{2 A}-\mathbf{C}, \mathbf{3 A}-\mathbf{C}$ ), which were attained at the addition of $5 \mathrm{~g} / \mathrm{L} \mathrm{FeCl}_{3}, 50 \mathrm{~g} / \mathrm{L} \mathrm{NaCl}, 20 \mathrm{~g} / \mathrm{L}$ molasses at pulp density of $5 \% w / v$ (for semi-direct bioleaching) and $2 \% w / v$ (for direct bioleaching). The mixotrophic bacterium Citrobacter sp. (as a single culture) which exhibited the excellent selectivity of lead bioleaching to copper and zinc might be more beneficial for subsequent copper and zinc leaching processes than chemolithoautotrophic bacteria used in previous studies (listed in Table 2), which were not selective to zinc (Pacholewska, 2004; Baba et al., 2011; Ghassa et al., 2014), while selectivity for copper was not determined (Jiang et al., 2008; Mejía et al., 2012). It is reported that galena $(\mathrm{PbS})$ that is often associated with zinc sulfides such as sphalerite $(\mathrm{ZnS})$ and copper sulfides such as chalcopyrite $\left(\mathrm{CuFeS}_{2}\right)$ frequently makes passivation layers that hinder $\mathrm{Cu}$ and $\mathrm{Zn}$ dissolution (Dutrizac, 1986; Dutrizac and Chen, 1990; Da Silva et al., 2003).

The overall reaction of $\mathrm{PbS}$ dissolution in the presence of $\mathrm{FeCl}_{3}$ and $\mathrm{NaCl}$ and the Gibbs free energy for $\mathrm{PbS}$ oxidation are presented in Eqs. (2)-(8) (Shock et al., 1997; Chase, 1998). According to the Gibbs free energy values, the reactions had negative values, indicating the spontaneous reaction. However, the negative values obtained said nothing about the kinetics because the kinetics was affected by the slowest reaction step in the leaching process. For example, Gibbs free energy for the dissolution of chalcopyrite $\left(\mathrm{CuFeS}_{2}\right)$ in acidified ferric sulfate solution was negative (Hiroyoshi et al., 2000), but in fact, the copper extraction level in this system was very low, and long periods of time and high temperature were needed for the complete dissolution (Dutrizac, 1978). Moreover, if the dissolution process brings about non-porous solid products on the mineral surfaces, then the products can preclude the leaching agents such as ferric iron from reacting with the minerals and thus retard the kinetics, while the reactions might proceed faster or slower. The presence of bacteria acts as the catalyst, thus accelerating the reactions. In this study, the bacterium Citrobacter sp. was shown to increase $\mathrm{Pb}$ dissolution from the galena concentrate compared to abiotic control leaching without bacteria.

The oxidation reaction of $\mathrm{PbS}$ by ferric ions:

$$
\begin{aligned}
P b S_{(s)}+2 \mathrm{Fe}_{(a q)}^{3+} \rightarrow \mathrm{Pb}_{(a q)}^{2+}+2 \mathrm{Fe}_{(a q)}^{2+} & +S_{(s)}^{0} \\
\Delta \mathrm{G}_{\mathrm{r} 1,298 \mathrm{~K}} & =-76.1 \mathrm{~kJ} / \mathrm{mol}
\end{aligned}
$$

Oxidation reaction of elemental sulfur and ferrous ions by bacteria:

$$
\begin{gathered}
2 \mathrm{Fe}_{(a q)}^{2+}+0.5 \mathrm{O}_{2(a q)}+2 \mathrm{H}_{(a q)}^{+} \stackrel{\text { bacteria }}{\rightarrow} 2 \mathrm{Fe}_{(a q)}^{3+}+\mathrm{H}_{2} \mathrm{O}_{(l)} \\
\Delta \mathrm{G}_{\mathrm{r} 2,298 \mathrm{~K}}=-88.6 \mathrm{~kJ} / \mathrm{mol} \\
S_{(s)}^{0}+0.5 \mathrm{O}_{2(a q)}+\mathrm{H}_{2} \mathrm{O}_{(l)} \stackrel{\text { bacteria }}{\rightarrow} \mathrm{H}_{2} \mathrm{SO}_{4(a q)} \\
\Delta \mathrm{G}_{\mathrm{r} 3,298 \mathrm{~K}}=-452.8 \mathrm{~kJ} / \mathrm{mol}
\end{gathered}
$$


Reaction of $\mathrm{Pb}$ ions with chloride or sulfate ions:

$$
\begin{aligned}
\mathrm{Pb}_{(a q)}^{2+}+\mathrm{Cl}_{(a q)}^{-} & \rightarrow \mathrm{PbCl}_{(a q)}^{+} \\
& \Delta \mathrm{G}_{\mathrm{r} 4,298 \mathrm{~K}}=-7.9 \mathrm{~kJ} / \mathrm{mol} \\
\mathrm{Pb}_{(a q)}^{2+}+2 \mathrm{Cl}_{(a q)}^{-} & \rightarrow \mathrm{PbCl}_{2(a q)} \\
& \Delta \mathrm{G}_{\mathrm{r} 5,298 \mathrm{~K}}=-11.1 \mathrm{~kJ} / \mathrm{mol} \\
\mathrm{Pb}_{(a q)}^{2+}+3 \mathrm{Cl}_{(a q)}^{-} & \rightarrow \mathrm{PbCl}_{3(a q)}^{-} \\
& \Delta \mathrm{G}_{\mathrm{r} 6,298 \mathrm{~K}}=-9.4 \mathrm{~kJ} / \mathrm{mol} \\
\mathrm{Pb}_{(a q)}^{2+}+\mathrm{SO}_{4(a q)}^{2-} & \rightarrow \mathrm{PbSO}_{4(s)} \\
& \Delta \mathrm{G}_{\mathrm{r} 7,298 \mathrm{~K}}=-44.3 \mathrm{~kJ} / \mathrm{mol}
\end{aligned}
$$

Correspondingly, the molasses introduced into the bioleaching systems enabled the mixotrophic bacterium Citrobacter sp. to gain the energy needed to carry out its metabolic processes from organic compounds (as organic carbon source) in the presence of oxygen in which the bacterium was essential participants in the complete oxidation of organic compounds $\left(\mathrm{CH}_{2} \mathrm{O}\right)$ to $\mathrm{CO}_{2}+\mathrm{H}_{2} \mathrm{O}$ along with a much greater yield of energy [Eq. (9)]. By utilizing the organic carbon, the bacterium was capable of producing large amounts of biosurfactants (including EPS), which mediated tight bacterial adherence to galena concentrate as well as kept solubilizing ferric iron even at $\mathrm{pH}>4.0$ as a result of complexation of the ferric ion with EPS (Vardanyan et al., 2020).

$$
\begin{aligned}
\mathrm{CH}_{2} \mathrm{O}+\mathrm{O}_{2(\mathrm{~g})} \rightarrow \mathrm{CO}_{2(g)}+\mathrm{H}_{2} \mathrm{O}_{(l)} & \\
& \Delta \mathrm{G}_{\mathrm{r} 8,298 \mathrm{~K}}=-500.4 \mathrm{~kJ} / \mathrm{mol}
\end{aligned}
$$

In summary, the current study presents a biohydrometallurgical leaching process of the Indonesian galena concentrate containing chalcopyrite and sphalerite at room temperature and atmospheric pressure, which exhibits selective leaching of lead to copper and zinc where this leaching technique prevents the release of $\mathrm{SO}_{2}$ and lead $(\mathrm{Pb})$ dust emission. It is necessary to conduct further research to obtain the optimum lead bioleaching conditions by adapting the bacterium to galena concentrate first before employing it in the bioleaching systems since the current leaching study uses non-adapted bacteria with a low pulp density $(2 \% w / v)$. By having the adapted bacteria, the higher pulp density in the leaching process can be increased, and $\mathrm{Pb}$ toxicity of higher pulp density can be reduced. Compared to the smelting technology currently used in the $\mathrm{Pb}$ extraction from galena $(\mathrm{PbS})$, the biohydrometallurgical $\mathrm{Pb}$ leaching can potentially compete because of its advantage in the following aspects: more ecofriendly method, energy-saving leaching process, selective leaching of $\mathrm{Pb}$ to $\mathrm{Cu}$ and $\mathrm{Zn}$. The selective $\mathrm{Pb}$ leaching to $\mathrm{Cu}$ and $\mathrm{Zn}$ demonstrated in this study thus makes a subsequent $\mathrm{Cu}$ and $\mathrm{Zn}$ extraction much easier in the downstream process (through biohydrometallurgical or hydrometallurgical route) since $\mathrm{Pb}$ has been removed. Moreover, the bacterium Citrobacter sp. in this study has shown to have the capacity to extract $\mathrm{Pb}$ from galena concentrate in the LB medium containing high
$\mathrm{NaCl}$ concentration, therefore in the further research, the use of $\mathrm{NaCl}$ can be replaced with seawater, which is commonly used in mining and metallurgy industries, whereas tryptone can be substituted by molasses.

\section{CONCLUSION}

The present study has shown that an iron- and sulfuroxidizing mixotrophic bacterium (Citrobacter sp.) used in this study is capable of extracting lead $(\mathrm{Pb})$ from the Indonesian galena concentrate which achieves the highest extraction level of $90 \mathrm{~g}$ lead dissolved $/ \mathrm{kg}$ galena concentrate using direct bioleaching method at bioleaching parameters of $2 \% w / v$ pulp density, $5 \mathrm{~g} / \mathrm{L} \mathrm{FeCl}_{3}, 50 \mathrm{~g} / \mathrm{L} \mathrm{NaCl}$, $20 \mathrm{~g} / \mathrm{L}$ molasses and a rotation speed of $180 \mathrm{rpm}$ at room temperature $\left(25^{\circ} \mathrm{C}\right)$. The results of this study may, therefore, be advantageous to the improvement of $\mathrm{Pb}$ leaching from sulfide ores through a more environmentally friendly biohydrometallurgical route.

\section{DATA AVAILABILITY STATEMENT}

The raw data supporting the conclusions of this article will be made available by the authors, without undue reservation, to any qualified researcher.

\section{AUTHOR CONTRIBUTIONS}

EAP performed the experiments under the supervision of SKC. SKC wrote the manuscript, while MZM made figures and tables. All authors revised the manuscript.

\section{FUNDING}

This work was funded by a grant from the Research Program (P3MI), Institute for Research and Community Services, Institut Teknologi Bandung, Indonesia, to SKC, and was partially funded by the Indonesian Ministry of Research and Technology/National Agency for Research and Innovation, and Indonesian Ministry of Education and Culture, under World Class University Program managed by Institut Teknologi Bandung.

\section{ACKNOWLEDGMENTS}

We thank all the students of the Geomicrobiology-Biomining \& Biocorrosion Laboratory and Microbial Culture Collection Laboratory, Biosciences and Biotechnology Research Center (BBRC), Institut Teknologi Bandung for their cooperation and assistance. We gratefully acknowledge Ronny Winarko (The University of British Columbia, Canada) for helpful discussion. We also thank Dr. Zhen Yu and Dr. Eldon R. Rene for their constructive comments. 


\section{REFERENCES}

Allen, M. A., and Igboayaka, E. C. (2019). The leaching behaviour of HNO3 solution in ishiagu ore, Ebonyi State Nigeria. Umudike J. Eng. Technol. 5, 130-138. doi: 10.33922/j.ujet_v5i1_15

Anugrah, R. I., Mubarok, M. Z., and Amalia, D. (2017). "Study on the leaching behavior of galena concentrate in fluosilicic acid solution using hydrogen peroxide as oxidant," in Proceedings of the 1st International Process Metallurgy Conference (IPMC 2016). (Bandung: IPMC), 030006. doi: 10.1063/1.4974417

Aydoğan, S., Aras, A., Uçar, G., and Erdemoğlu, M. (2007). Dissolution kinetics of galena in acetic acid solutions with hydrogen peroxide. Hydrometallurgy 89, 189-195. doi: 10.1016/j.hydromet.2007.07.004

Baba, A. A., and Adekola, F. A. (2013). Solvent extraction of $\mathrm{Pb}$ (II) and $\mathrm{Zn}$ (II) from a Nigerian galena ore leach liquor by tributylphosphate and bis $(2,4,4-$ trimethylpentyl)phosphinic acid. J. King Saud Univ. Sci. 25, 297-305. doi: 10. 1016/j.jksus.2013.07.003

Baba, A. A., Adekola, F. A., Atata, R. F., Ahmed, R. N., and Panda, S. (2011). Bioleaching of $\mathrm{Zn}(\mathrm{II})$ and $\mathrm{Pb}$ (II) from Nigerian sphalerite and galena ores by mixed culture of acidophilic bacteria. Trans. Nonferrous Metals Soc. China 21, 2535-2541. doi: 10.1016/S1003-6326(11)61047-9

Bang, S. S., Deshpande, S. S., and Han, K. N. (1995). The oxidation of galena using Thiobacillus ferrooxidans. Hydrometallurgy 37, 181-192. doi: 10.1016/ 0304-386X(94)00059-C

Berg, G., Seech, A. G., Lee, H., and Trevors, J. T. (1990). Identification and characterization of a soil bacterium with extracellular emulsifying activity. J. Environ. Sci. Health A Environ. Sci. Eng. Toxicol. 25, 753-764. doi: 10.1080/ 10934529009375595

Chaerun, S. K., Frideni, Y. P., Minwal, W. P., Ichlas, Z. T., and Mubarok, M. Z. (2018). Bacterial leaching of an Indonesian complex copper sulfide ore using an iron-oxidizing indigenous bacterium. Microbiol. Indones 12, 1-6. doi: 10.5454/ mi.12.1.1

Chaerun, S. K., Sulistyo, R. S., Minwal, W. P., and Mubarok, M. Z. (2017). Indirect bioleaching of low-grade nickel limonite and saprolite ores using fungal metabolic organic acids generated by Aspergillus niger. Hydrometallurgy 174, 29-37. doi: 10.1016/j.hydromet.2017.08.006

Chaerun, S. K., Tazaki, K., and Okuno, M. (2013). Montmorillonite mitigates the toxic effect of heavy oil on hydrocarbon-degrading bacterial growth: implications for marine oil spill bioremediation. Clay Miner. 48, 639-654. doi: 10.1180/claymin.2013.048.4.17

Chase, M. W. Jr. (1998). NIST-JANAF thermochemical tables. J. Phys. Chem. Ref. Data Monograph 9:1.

Da Silva, G. (2004). Kinetics and mechanism of the bacterial and ferric sulphate oxidation of galena. Hydrometallurgy 75, 99-110.

Da Silva, G., Lastra, M. R., and Budden, J. R. (2003). Electrochemical passivation of sphalerite during bacterial oxidation in the presence of galena. Miner. Eng. 16, 199-203. doi: 10.1016/S0892-6875(03)00010- 14

Dutrizac, J. E. (1978). The kinetics of dissolution of chalcopyrite in ferric ion media. MTB 9, 431-439. doi: 10.1007/BF02654418

Dutrizac, J. E. (1986). The dissolution of galena in ferric chloride media. MTB 17, 5-17. doi: 10.1007/BF02670814

Dutrizac, J. E., and Chen, T. T. (1990). The effect of the elemental sulfur reaction product on the leaching of galena in ferric chloride media. MTB 21, 935-943. doi: 10.1007/BF02670264

Flemming, H.-C., and Wingender, J. (2010). The biofilm matrix. Nat. Rev. Microbiol. 8, 623-633. doi: 10.1038/nrmicro2415

Garcia, O. Jr., Tuovinen, O. H., and Bigham, J. M. (1995). Oxidation of galena by Thiobacillus ferrooxidans and Thiobacillus thiooxidans. Can. J. Microbiol. 41, 508-514. doi: 10.1139/m95-067

Ghassa, S., Boruomand, Z., Abdollahi, H., Moradian, M., and Akcil, A. (2014). Bioleaching of high grade $\mathrm{Zn}-\mathrm{Pb}$ bearing ore by mixed moderate thermophilic microorganisms. Sep. Purif. Technol. 136, 241-249. doi: 10.1016/j.seppur.2014. 08.029

Govender, Y., and Gericke, M. (2011). Extracellular polymeric substances (EPS) from bioleaching systems and its application in bioflotation. Miner. Eng. 24, 1122-1127. doi: 10.1016/j.mineng.2011.02.016

Greet, C., and Smart, R. S. C (2002). Diagnostic leaching of galena and its oxidation products with EDTA. Miner. Eng. 15, 515-522. doi: 10.1016/S0892-6875(02) 00075-4
Hiroyoshi, N., Miki, H., Hirajima, T., and Tsunekawa, M. (2000). A model for ferrous-promoted chalcopyrite leaching. Hydrometallurgy 57, 31-38. doi: 10. 1016/S0304-386X(00)00089-X

Jiang, L., Zhou, H., Peng, X., and Ding, Z. (2008). Bio-oxidation of galena particles by Acidithiobacillus ferrooxidans. Particuology 6, 99-105.

Kim, S.-H., Henein, H., and Warren, G. W. (1986). An investigation of the thermodynamics and kinetics of the ferric chloride brine leaching of galena concentrate. MTB 17, 29-39. doi: 10.1007/BF02670816

Liao, M. X., and Deng, T. L. (2004). Zinc and lead extraction from complex raw sulfides by sequential bioleaching and acidic brine leach. Miner. Eng. 17, 17-22. doi: 10.1016/j.mineng.2003.09.007

Long, H., Chai, L., Liu, H., and Qin, W. (2009). Hydro-chemical conversion of galena in FeCl3-KCl solution. Trans. Nonferrous Metals Soc. China 19, 1331-1335. doi: 10.1016/S1003-6326(08)60445-8

Mejía, E. R., Ospina, J. D., Márquez, M. A., and Morales, A. L. (2012). "Bioleaching of Galena (PbS)," in Fourier Transform-Materials Analysis, ed. S. M. Salih (Croatia: InTech), 191-206.

Mubarok, M. Z., Winarko, R., Chaerun, S. K., Rizki, I. N., and Ichlas, Z. T. (2017). Improving gold recovery from refractory gold ores through biooxidation using iron-sulfur-oxidizing/sulfur-oxidizing mixotrophic bacteria. Hydrometallurgy 168, 69-75. doi: 10.1016/j.hydromet.2016.10.018

Pacholewska, M. (2004). Bioleaching of galena flotation concentrate. Physicochem. Probl. Miner. Process. 38, 281-290.

Pashkov, G. L., Mikhlina, E. V., Kholmogorov, A. G., and Mikhlin, Y. L. (2002). Effect of potential and ferric ions on lead sulfide dissolution in nitric acid. Hydrometallurgy 63, 171-179. doi: 10.1016/S0304-386X(01)00221-3

Qin, W., Liu, H., Tang, S., and Sun, W. (2009). Preparation of lead sulfate powder directly from galena concentrates. Trans. Nonferrous Metals Soc. China 19, 479-483. doi: 10.1016/S1003-6326(08)60299-X

Shock, E. L., Sassani, D. C., Willis, M., and Sverjensky, D. A. (1997). Inorganic species in geologic fluids: correlations among standard molal thermodynamic properties of aqueous ions and hydroxide complexes. Geochimica Cosmochimica Acta 61, 907-950. doi: 10.1016/S0016-7037(96) 00339-0

Vardanyan, N., Badalyan, H., Markosyan, L., Vardanyan, A., Zhang, R., and Sand, W. (2020). Newly isolated Acidithiobacillus sp. Ksh from Kashen copper ore: peculiarities of EPS and colloidal exopolysaccharide. Front. Microbiol. 11:1802. doi: $10.3389 /$ fmicb.2020.01802

Warren, G. W., Kim, S., and Henein, H. (1987). The effect of chloride ion on the ferric chloride leaching of galena concentrate. MTB 18, 59-69. doi: 10.1007/ BF02658432

Wu, Z., Dreisinger, D. B., Urch, H., and Fassbender, S. (2014). The kinetics of leaching galena concentrates with ferric methanesulfonate solution. Hydrometallurgy 142, 121-130. doi: 10.1016/j.hydromet.2013.10.017

Ye, M., Yan, P., Sun, S., Han, D., Xiao, X., Zheng, L., et al. (2017). Bioleaching combined brine leaching of heavy metals from lead-zinc mine tailings: transformations during the leaching process. Chemosphere 168, 1115-1125. doi: 10.1016/j.chemosphere.2016.10.095

Zárate-Gutiérrez, R., Gregorio-Vázquez, L., and Lapidus, G. T. (2015). Selective leaching of lead from a lead-silver-zinc concentrate with hydrogen peroxide in citrate solutions. Can. Metall. Q. 54, 305-309. doi: 10.1179/1879139515Y. 0000000020

Zárate-Gutiérrez, R., Lapidus, G. T., and Morales, R. D. (2010). Pressure leaching of a lead-zinc-silver concentrate with nitric acid at moderate temperatures between 130 and $170^{\circ} \mathrm{C}$. Hydrometallurgy 104, 8-13. doi: 10.1016/j.hydromet. 2010.04.001

Conflict of Interest: The authors declare that the research was conducted in the absence of any commercial or financial relationships that could be construed as a potential conflict of interest.

Copyright (C) 2020 Chaerun, Putri and Mubarok. This is an open-access article distributed under the terms of the Creative Commons Attribution License (CC BY). The use, distribution or reproduction in other forums is permitted, provided the original author(s) and the copyright owner(s) are credited and that the original publication in this journal is cited, in accordance with accepted academic practice. No use, distribution or reproduction is permitted which does not comply with these terms. 